$$
\begin{aligned}
& S F 55 \\
& A_{3} B_{8}
\end{aligned}
$$


ฮ 


\title{
THE LIVE-STOCK INDUSTRY IN SOUTH AMERICA
}

\author{
L. B. BURK
}

Investigator in Marketing Live Stock and Meats, Bureau of Agricultural Economics AND

E. Z. RUSSELL

Specialist in Swine Husbandry, Bureau of Animal Industry

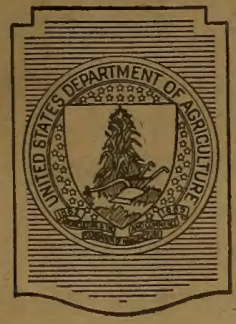

UNITED STATES DEPARTMENT OF AGRICULTURE DEPARTMENT CIRCULAR 228

Washington, D. C. 



\section{SF 55 \\ A3B8}

\section{THE LIVE-STOCK INDUSTRY IN SOUTH AMERIGA.}

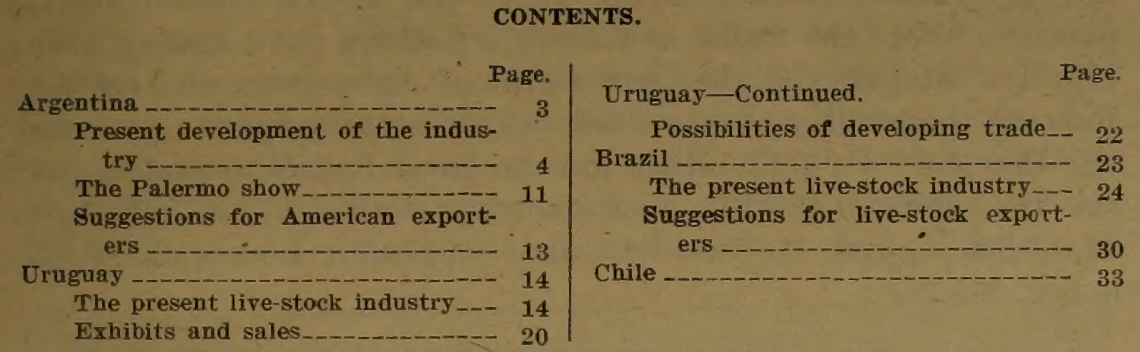

Live-stock breeders in the United States, like all agricultural producers, are manifesting a lively interest in world markets. They are especially interested in the possibilities of exporting cattle, sheep, and hogs to South America. Some knowledge of the present development of the industry there and of the types and qualities of live stock desired by South American stockmen is necessary to enable breeders in this country to plan their operations intelligently.

The following observations and suggestions are based on personal investigations made by representatives of the United States Department of Agriculture in Argentina, Uruguay, Brazil, and Chile.

\section{ARGENTINA.}

Argentina is principally an agricultural and stock-raising country and ranks among the leading countries of the world in the production of grain, cattle, and sheep.

The grain and leading stock-raising sections, comprising the Provinces of Buenos Aires, Cordoba, and Santa Fe, resemble the level fertile corn and alfalfa regions of Kansas, Nebraska, and Colorado. The climate, however, is more mild, much like that of our Southern States. In the extreme eastern part of the country there is plenty of rainfall to produce satisfactory crops of corn and potatoes when modern methods of planting and cultivation are used, but southward and westward of the central part of the Province of Buenos Aires the rainfall diminishes rapidly.

The mild climate, fertile soil, and wide stretches of alfalfa, which remains green and is satisfactorily grazed throughout the year, make 
Argentina almost an ideal country in which to produce live stock of all kinds. In addition to corn and alfalfa, large crops of wheat, oats, flax, and barley are harvested annually.

\section{PRESENT DEVELOPMENT OF THE INDUSTRY.}

Until recently development of the live-stock industry has been largely confined to beef cattle, sheep, and horses, but during the past few years the swine and dairy industries have been growing rapidly. Statistics of the Department of Agriculture of Argentina showing the number of live stock in that country for the year ending December 31, 1917, which are the latest figures available, indicate the extent of the live-stock industry: Cattle, $27,052,586$; sheep, $44,855,000$; goats, 4,583,330; swine, $3,259,456$; horses, 8,823,237; mules, 595,194 .

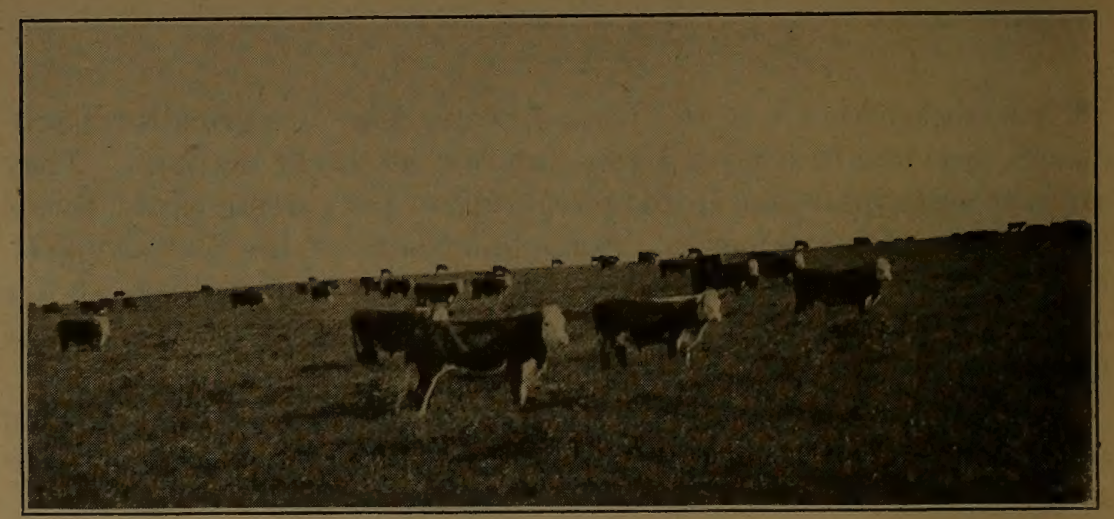

FrG. 1.-Hereford cattle grazing on alfalfa in Argentina.

THE BEEF-CATTLE INDUSTRY.

The Shorthorn breed of cattle has been the most popular for many years, although recently lively interest is being manifested in the Hereford, Aberdeen Angus, and Polled Shorthorn breeds. The type generally seen is slightly longer in body, legs, and neck and lacks the smoothness of the more compact type of this country. This type, no doubt, is the result of an attempt to maintain the size of the range steer in Argentina. In the United States the necessity for making rapid and economical gains in the feed lot has caused the compact, short-legged, smooth, early maturing type of animal to predominate.

In traveling from one breeder's ranch to another, many of which are $5,000,10,000$ and 15,000 acres in size, large herds of excellent breeding cows with straight-lined, wide-backed calves by their sides are seen. Some are pure bred, but the larger part of them are grade cows of superior individuality. Pure-bred bulls of good type are allowed to run with them. Steers of different ages in the adjoining 
pastures, growing fat on the green alfalfa, show the splendid results of crossing pure-bred bulls with high-grade cows.

Live stock graze all the year round on'natural pasture. It is understood that during a very hard winter small quantities of feed in the form of oats or alfalfa are provided for a short period, but as a general thing feeding is unusual and breeders avoid it because of extra expense.

The value of the grading-up practices which have been in progress for many years in Argentina was brought out clearly in the cattle seen in September, 1920, at the stockyard in Buenos Aires. The type, size, and finish of the steers were strikingly uniform and practically all carried the Shorthorn markings. At that market, cattle are sold by the head and not by weight, and are auctioned off instead of

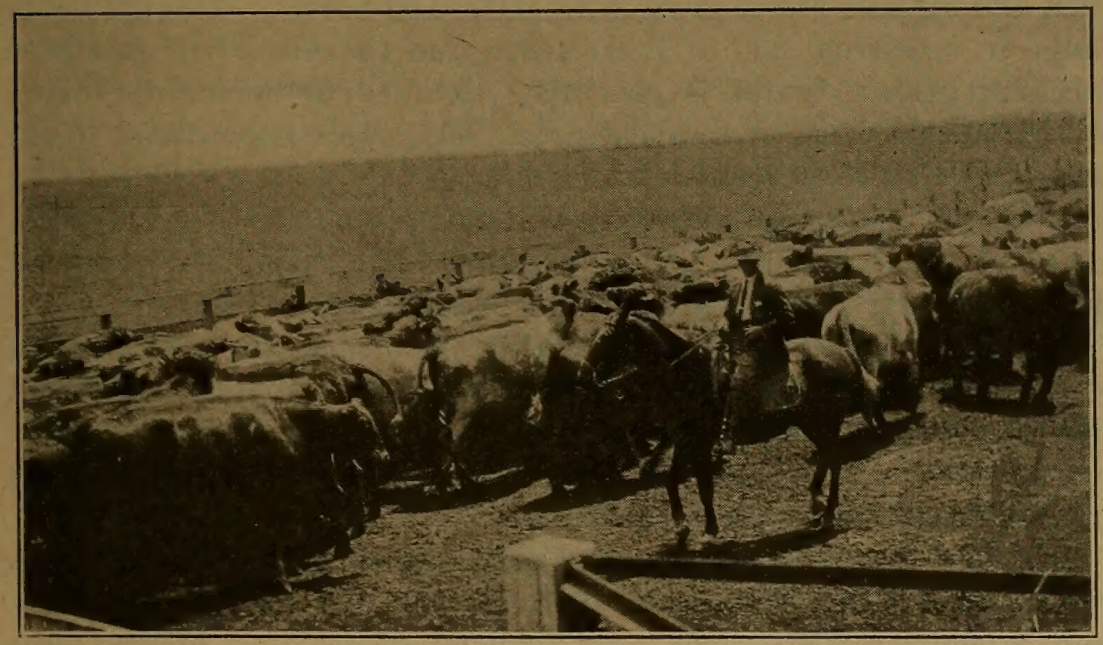

Fra. 2.-Fat steers taken off alfalfa at the close of winter in Argentina. Age, 3 jears ; average weight, 1,300 pounds.

being sold as they are in the larger markets of this country. At that time choice, grass, fat steers were selling for the equivalent of 7 cents per pound.

The daily yardage charge at Buenos Aires in 1920 was about 45 cents per head for cattle, 20 cents for hogs, and $12 \frac{1}{2}$ cents for sheep. In addition, the seller allowed the buyer 15 cents per head on cattle and 45 cents per head on hogs to reimburse him for possible loss on account of bruises, tuberculosis, or other diseases. No allowance was made for sheep. The commission for selling was 3 per cent of the gross sales.

The demand for pure-bred cattle in Argentina is limited, but good prices are being paid for well-fitted animals of the type and breeding desired. It should be remembered that breeders in Argentina demand 
the best that this country can offer and that mediocre, half-fat animals are not wanted at any price.

The rate of exchange, tariff, and outbreak in Brazil of rinderpest, a very fatal and contagious disease, have caused trade conditions between the United States and Argentina to become unsettled temporarily, but it is believed that when conditions become normal there will be considerable demand for breeding cattle of our leading breeds, as well as for hogs, sheep, and horses.

SHEEP RAISING.

Sheep raising ranks next in importance to the cattle industry in Argentina. In the Province of Buenos Aires, which is the most important sheep-raising district, sheep are raised entirely in the open and are allowed to graze with cattle and horses. The flat fields range in size from 250 to 1,800 acres, and the black soil produces excellent grass. Water is generally provided by windmills, often located at the corner of four pastures. The water is good and found at a depth of 4 to 30 feet.

A flock of sheep generally consists of from 500 to 1,000 head. However, some breeders are subdividing their farms and reducing the size of their flocks in order to give better care.

In the southern part of the Province of Buenos Aires the Lincoln seems to be best adapted to the climatic conditions and is the-breed which gives the largest profits, both from the standpoint of quantity of meat and weight of fleece. Some grade Merinos in good condition were also seen in the fields.

It is said that 25 years ago most of the sheep were Merinos. Special attention was given to wool production, but little or no attention to mutton. With the establishment of packing houses came higher prices for mutton and it became more profitable to produce sheep for mutton than for wool. This caused a greater demand for sheep of the mutton type, and both Merinos and native sheep were crossed with Lincoln rams in order to produce an animal more nearly that type. As a result not only an increased production of meat was obtained, but also a heavier fleece of coarse quality. Although this coarse wool usually commands a lower price than the grade Merino, the difference is claimed to be offset largely by the heavier weight of the fleece.

During the war the prices of all kinds of wool were so high that the profit from wool, even if it was coarse, was greater than that from meat. At the present time the prices of coarse wool are again so low that breeders will undoubtedly find greater profit in the production of meat and most of them will prefer to increase production along that line. However, some breeders are considering 
the use of Merino rams to improve the quality of wool, but how extensively this will be done is uncertain.

In the warmer northern and western Provinces Lincolns do not develop so well; the fleece is shorter and coarser and does not have so good a color or luster as in the southern regions. It is generally considered that this difference is due to the climate and quality of pasture.

In the Territories of Neuquen, Rio Negro, and Chubut, greater attention is given to the quality of the wool. Most of the sheep are crossbreds produced by crossing high-grade Merinos with Romney Marsh and Lincoln rams. Lincolns, however, are not used extensively, as they have not given good results. In the Territories of Santa Cruz and Tierra del Fuego the Romney Marsh breed predominates and for the present it does not seem that other breeds will be introduced.

There are also many ranch owners who have large pure bred flocks. Ordinarily high-class rams sell well, but during the fall of 1920 they sold slowly, probably because of the low price of wool. Every year a considerable number of pure-bred sheep are imported from England and other countries.

The mortality caused by storms and winter weather does not exceed 5 per cent in normal years. Stomach worms and scab are also liable to cause some Toss in the flocks. Stomach worms are not bad except in wet years, when the grass is especially rank. Scab is controlled by dipping three consecutive times, 15 to 20 days apart, the first dipping usually being done immediately after shearing. This is followed by special applications by hand if spots of scab are still visible. Dipping after shearing is always beneficial, but if it is done too early in the spring there is danger of pneumonia. About a month before lambing begins the sheep are given a bath, followed by hand treatment.

The workmen employed for the care of sheep are generally Argentinians, but a few are from southern Spain. On the better farms a man and his family are employed who live in a house some distance from the main farm buildings and who have the exclusive care of 1,000 to 1,500 sheep. These men are called "puesteros."

The herders and men for general work on a ranch received in $1915 \$ 12$ to $\$ 14$ a month with food and lodging. The puesteros who, with their families, had charge of a flock, received during the same period $\$ 16$ to $\$ 20$ per month and in addition a small interest in the lambs, which would amount to about $\$ 7$ a month. In some cases the owner of the farm provided the entire supply of food for the puestero and his family; in other cases he provided only the meat. Since 1915 wages have increased 30 to 40 per cent and cost of food about 80 per cent. 
Sheep shearing covers a period of several weeks. Approximately 80 per cent of it is done by machine and 20 per cent by hand. Many of the landowners have their own shearing machines, but some make contracts with professional shearers.

When the sheep are ready for market they are driven to the station and loaded on stock cars that go direct to the market, very much the same as is done in the United States.

In the Buenos Aires sheep-grazing region the land belongs to private individuals. It is estimated that about half of the land used for pasture is managed by the owner and half is rented. In 1914 rents varied from $\$ 1.60$ to $\$ 2.25$ per acre. Contracts usually cover three to five years. Since 1914 rents have advanced nearly $\$ 1$ per acre.

Recently the high rents have brought about a tendency on the part of live-stock breeders in the Province of Buenos Aires to devote more time to the breeding of cattle than sheep because, as a general thing, cattle return larger profits. Therefore, the high price of beef and the low price of wool, if they continue, will probably cause the interest in sheep breeding to diminish. It is also found that sheep destroy a stand of alfalfa more quickly and require more attention than cattle. In certain districts where grass is plentiful dairying is also tending to replace the sheep industry. The rate at which this change will take place will depend on the future prices of wool and mutton as compared with the prices of beef and dairy products.

HOG RAISING.

At the present time comparatively few Argentine farmers are raising hogs. However, the mild climate and long growing season, together with the abundance of corn and alfalfa, furnish very good conditions for economical pork production, and it is believed that the industry will expand within the next few years, and that eventually a much larger percentage of the corn crop will be marketed on the hoof than at present. An increased number of swine will doubtless bring about a greater demand for breeding animals and the United States seems to be the logical place to get them.

Most of the hogs are produced in the corn and alfalfa sections. It is the general practice in most sections to raise hogs in small pens without green feed.

During recent years a few ranchmen have begun producing hogs in large numbers and on some ranches as many as 5,000 or 10,000 are raised annually. They are allowed to graze over the alfalfa fields and are driven by men on horseback much the same as cattle. On the large ranches hogs are raised entirely in the open and barns or sheds are seldom provided.

The principal breeding seasons are the same as in the United States, except that the Argentina farmer breeds a larger number of sows 
in May and June than he does in November and December. As in this country, it is considered advantageous to have the larger percentage of pigs farrow in the spring, and September, October, and November are the spring months in Argentina. During the breeding season the sows and boars are turned into the alfalfa pastures. One boar is generally used for each 20 to 25 sows. The bred sows remain in these fields until a week or ten days before farrowing, when they are transferred to another alfalfa field and given a liberal ration of corn in addition to the alfalfa. The sows are closely watched and small piles of straw are placed in semicircles for the sows about to farrow. After farrowing, alfalfa is the only feed allowed for about 15 days, and then dry shelled corn becomes a part of the ration.

When the pigs are about three weeks old creeps are provided, so that corn is available at will. Best results are obtained when the corn is soaked before it is fed to young pigs, because most of the

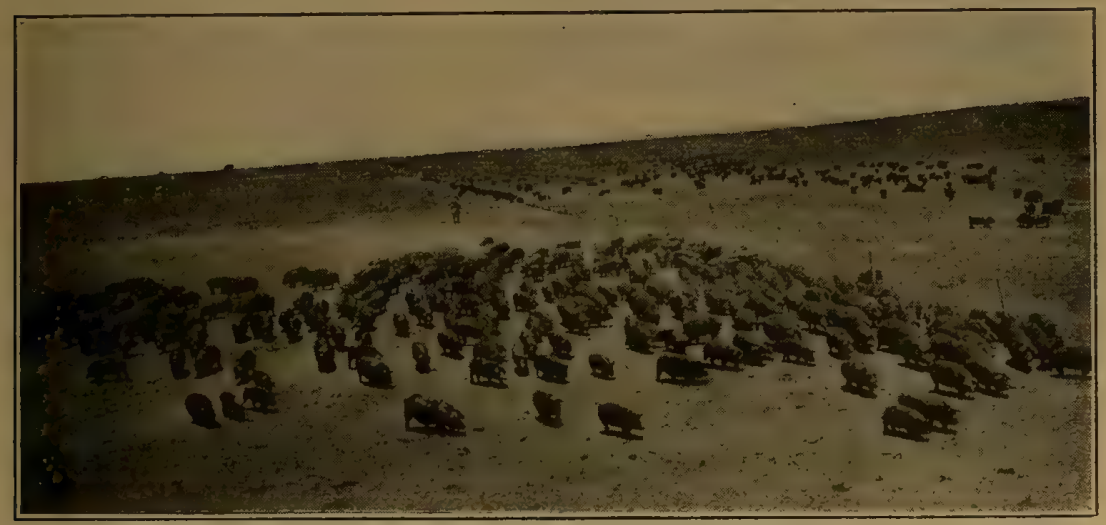

FiG. 3.-Hogs grazing on alfalfa in Argentina.

corn grown in Argentina is of a flint variety and is very hard. Automatic waterers are provided in all pastures. Usually the pigs wean themselves. After weaning they are allowed to graze on alfalafa and are fed corn until they weigh about 100 pounds. Then they are either fed a full corn ration in the alfalfa pastures or are allowed to "hog down" corn" in adjoining fields, until they attain market weight. Most of the hogs are sent to market when they are from 9 to 12 months old and weigh from 200 to 275 pounds.

Two diseases, cholera and foot-and-mouth disease, menace the swine industry, and have thus far prevented its making more rapid progress. Steps are now being taken, however, both to manufacture antihog-cholera serum in Argentina and to import it from the United States.

On August 17, 1920, receipts of hogs at the stockyards at Buenos Aires amounted to 2,102 head. These hogs were neither good nor $105982-22-2$ 
uniform in quality. They represented a mixture of Berkshire, Yorkshire, Poland China, and Duroc-Jersey breeding, most of which were black in color, some spotted, and a few white. There was not a single full load that would be graded as good on any of our leading markets. Some good individuals were included in most of the loads, but, taken as a whole, they showed little or no attempt to produce a uniform, easy-feeding animal. Packer buyers, however, made the statement that most of the good-quality hogs raised in Argentina do not go through the public stockyards, but are bought direct from the producer.

The hogs were sorted before being sold. A good many pigs, thin in flesh, were sold as feeders at 8 to 10 cents a pound. Fat hogs brought about 12 cents on the same day. It was noted that stock hogs were neither vaccinated nor dipped before leaving the yards, which would seem to make their purchase a rather hazardous undertaking. There is no official system for price docking for stags, piggy sows, or diseased animals, such as is practiced in the United States. It was stated that about 8 per cent of the hogs killed were affected with tuberculosis.

Several large packing plants in Buenos Aires and neighboring large cities supply a ready market for cattle, sheep, and hogs. All of these plants are located at some distance from the stockyards, most of them about 30 miles. This makes it necessary for packer buyers to reload and ship all the stock they purchase, thus entailing considerable expense and loss of time. Most of the meat produced is exported to. Europe, although some of it is sent to the United States.

\section{DAIRYING.}

The dairy industry of Argentina is growing and is proving a profitable business. So far the large number of beef-breeding cows that are milked in that country, together with the small population, has not been conducive to the rapid development of specialized dairying. However, the mild climate, long grazing season, and the availability of cheap grain are favorable conditions and, as the population increases, there will undoubtedly come a greater demand for dairy products and a corresponding increase in the demand for dairy cattle.

In the sections near the cities of Tandil, Buenos Aires, and Rosario the dairy industry already shows considerable development, and the Holstein-Friesian breed is the most prominent. In the past the export demand for butter and cheese has been a very important factor in the success of the dairy business.

With the exception of foot-and-mouth disease, which usually occurs once each year and sometimes twice, there are few diseases and pests which trouble cattle in the central and southern sections of the 
country. This disease is, of course, a particular menace to the dairy business, because it not only temporarily stops the flow of milk but frequently reduces by at least one-third the total flow for that particular lactation period.

\section{THE HORSE INDUSTRY.}

Argentina has a large surplus of good high-grade mares and geldings weighing 1,200 to 1,600 pounds, and it was said that such horses could be bought for $\$ 40$ to $\$ 50$ each. In that country the farmer keeps enough horses to make possible changing teams twice a day and feeds very little grain. The horses are worked half the day and

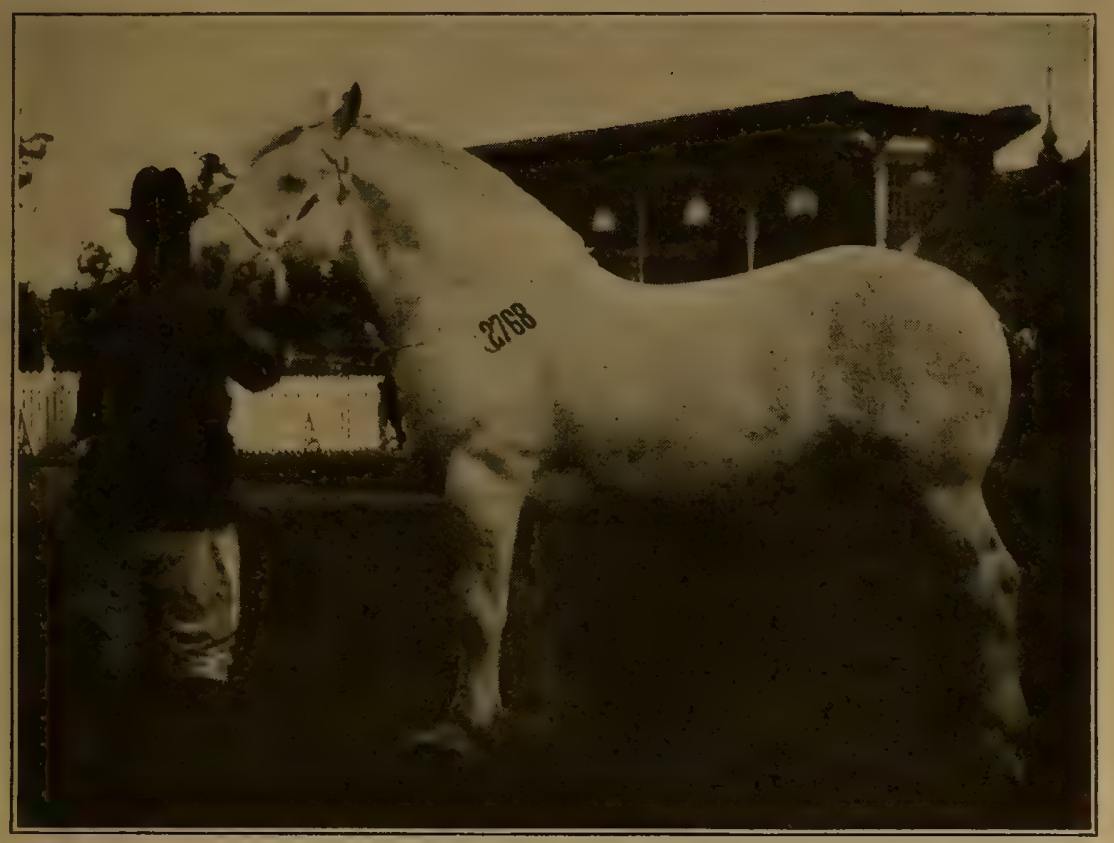

FiG. 4.-Percheron stallion at the 1920 International Live Stock Exposition, Buenos Aires, Argentina.

then turned into the alfalfa field to graze. They are never fed grain and worked throughout the day as in this country.

In view of the low price of horses, it does not seem probable that the demand for stallions from the United States will be very great during the next few years. At the Palermo show, however, a few Percherons, Clydesdales, and Shires, ranging from plain to fairly good, sold at $\$ 500$ to $\$ 1,000$ apiece.

THE PALERMO SHOW.

The Argentine International Live Stock Exposition, usually called the Palermo show, held at Buenos Aires in September of each 
year under the management of the Argentine Rural Society, serves as a good barometer of the demand for the qualities desired in live stock. The demand for high-class cattle in 1920 appeared to be generally good, while plain individuals sold very cheaply in comparison with the others. Of course an inferior individual occasionally brought a high price. Some phenomenal prices were paid for the grand champions of each class, the Shorthorn, Hereford, and Angus champions selling for $\$ 36,666, \$ 30,000$, and $\$ 11,660$, United States currency, respectively. Average prices, however, were not so high as they had been at previous shows. Imported cattle from the United States and England, of special breeding with which the buyers were familiar, brought very good prices, but it was reported that medium stock was practically unsalable.

The exposition grounds at Palermo are very beautiful and are kept in perfect condition. The buildings are elaborately designed and well arranged around the judging rings. All of the judging is done in the open. The rural society provides feed and care for all live stock sent for exhibition. However, foreign exhibitors should bear in mind that all the feeding is done by "peons," who usually are not skilled in handling animals.

The public seemed to be interested principally in cattle, which is not surprising in view of the large number of cattle on exhibition and the great interest in cattle production. The exhibit was, indeed, a beautiful sight. The large, well-arranged barns were filled completely with cattle of superior quality, well fitted and groomed. Approximately 1,800 Shorthorn bulls were exhibited. The judging of bulls especially was watched with the keenest interest by large crowds of enthusiastic spectators and the judges furnished by the English Royal Society were highly praised for their efficient work.

Arrangements for handling hogs are by no means as complete as those for cattle. The pens are uniform in size, about $3 \frac{1}{2}$ by 5 feet, which is entirely too small for the mature hogs shown in the United States. The hogs are penned in the barns in the order of their catalogue numbers; for example, all the aged Poland China boars may be ranged along one aisle, the aged Berkshire boars along another, and so on throughout the list, senior yearlings, junior yearlings, etc., following in order. This arrangement is convenient for the visitor but complicates matters for the exhibitor, as he frequently finds his animals scattered throughout the barn. The judging is done in much the same manner as in the United States, but the animals are not so carefully handled. One or more vigorous fights often occur while the hogs are being taken to and from the ring.

In 1920, 489 hogs were exhibited, apportioned by breeds and sexes as follows: 


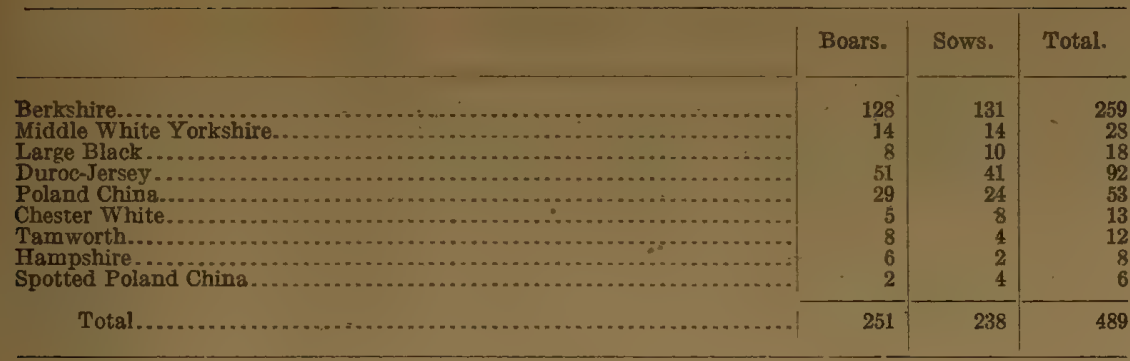

Most of the prize winners were extremely small animals of the type commonly known in this country as "hot blood." In the Poland China and Berkshire classes the judges invariably disqualified animals showing any white markings except the six white points. Apparently, however, low backs and poor feet or legs were disregarded. Excessive fat seemed to be desired.

Practically all the animals entered at the Palermo show are sold at auction. Sales of almost all classes of live stock begin on the opening day and are conducted each day of the show. Hogs are generally sold by catalogue number in the pen in which they are exhibited, and are not driven out into the arena or sale ring. All the hogs on exhibition are consigned to some auction firm and representatives of these various firms are on hand to sell the animals consigned to them when the numbers are called.

A selling commission of 6 per cent is paid by the purchaser. The auction firm selling the stock gets one-half of this commission and the other half goes to the Argentine Rural Society.

One very satisfactory feature of this sales system is that the auction firm assumes all the responsibility for collecting payment for the animals sold. The total amount of the sales is paid to the seller by the auction firms, and if for any reason the buyer can not or does not pay for the animal which he has purchased, the seller loses nothing.

The same general plan is followed in selling cattle and sheep. Cattle sales often continue a week or 10 days after the closing date of the show. It seemed probable that during the early part of the show a limited number of very good imported individuals from the United States of any of the beef breeds could have been sold at satisfactory prices.

\section{SUGGESTIONS FOR AMERICAN EXPORTERS.}

Argentine stockmen purchase most of their breeding stock during August and September. Practically all of these breeding animals are bought at public auction on the Palermo show grounds or in the various sale barns, which are located in the center of the re- 
tail business section of the city of Buenos Aires. Exports of live stock from the United States should be made in time to arrive at Buenos Aires and go through quarantine before the sale season opens. The quarantine period is 30 days for cattle and 15 days for hogs and sheep.

It is believed that some high-class bulls of the Shorthorn, Hereford, and Angus breeds would bring good prices. Shorthorns are in much more demand than other breeds, although good Holsteins are wanted by dairymen. Inferior animals are not wanted and should not be sent. A small number of selected females in prime condition should sell well.

Most of the hogs in Argentina are Berkshires yet, judging by the sale of the view herd sent down by the National Swine Growers' Association in 1920, Poland Chinas and Duroc-Jerseys are more in demand at present. The Argentine farmer wants large-type hogs although he is not now raising them. Good, large, well-fitted, mature boars and sows seem to sell well. The sows should be bred and safe in pig, and a doubtful breeder should not be shipped under any circumstances. All hogs should be immunized against cholera and tested for tuberculosis. The tuberculin test is not required, but the shipper should take this precaution for his own protection, as all animals are tested-by Argentine Government officials before they are released from quarantine.

\section{URUGUAY.}

Uruguay is not much larger than the State of Missouri. The climate and rolling prairie lands make it almost an ideal country for raising cattle and sheep. The climate is mild, with no snow in winter, and no excessive heat in summer. Montevideo, the capital, is located at the extreme southern end of the country, just seven hours by boat from Buenos Aires. It is the principal port, and all the railroads radiate from it.

\section{THE PRESENT LIVE-STOCK INDUSTRY.}

At the present time cattle and sheep raising are the principal industries in Uruguay. Only a limited number of hogs are produced, probably because of the fact that corn and other feeds essential to profitable pork production are more or less uncertain crops. Corn has never been extensively produced because of the lack of rainfall at the proper time, the periodical appearance of grasshoppers or locusts, and the crude methods of planting and cultivation. In a large part of the country the soil is closely underlaid with rock, which prevents the storing of moisture in the subsoil. The last census, taken in 1916, shows the following number of live stock in Uruguay: Cattle, $7,802,446$; sheep, 11,472,852; hogs, 303,958; horses, 567,154. 
HOG RAISING.

Hogs are not grown extensively in Uruguay. The breeds most commonly seen are Berkshires and Middle White Yorkshires. There are also a few Duroc-Jerseys and Poland Chinas. Hog cholera, tuberculosis, and foot-and-mouth disease are the chief diseases encountered.

The packing plants at Montevideo provide a good market at.any time for all the hogs produced.

For the reasons enumerated above it seems doubtful whether Uruguay will ever become an important hog-raising country.

\section{CATTLE RAISING.}

On the very large ranches large herds of cattle and sheep graze together. The grass remains green practically throughout the year,

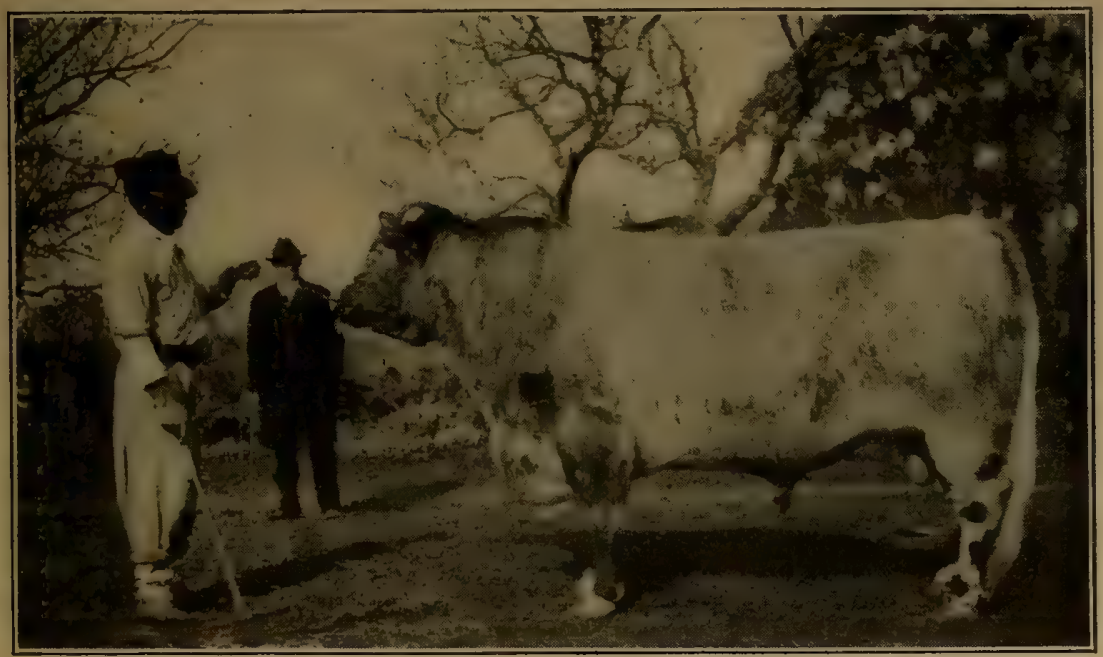

FIG. 5.--Shorthorn herd bull on a ranch near Paysandu. Uruguay.

and other feeding is seldom necessary. Many breeders who produce range bulls for sale sow oats for winter and early spring grazing, so that their bulls will make a good growth, and be in good condition for sale day. A large number of cattle breeders were visited in Uruguay, and all had good equipment for handling cattle.

The beef breeds rank in numbers about as follows: Hereford, $\mathrm{Na}$ tive, Shorthorn, Aberdeen Angus, Polled Hereford, and Polled Shorthorn. The number of Herefords is much larger than any of the others. The Native, a reddish cream-colored or black animal, is a very large breed which crosses well with the Hereford, Aberdeen Angus, and Shorthorn, and at the age of 3 years makes excellent beef. Such steers were selling for 7 cents a pound in August and September, 1920. 
There are rather striking differences in type between North American cattle and those found in Uruguay. Most of the bulls seen in Uruguay were a trifle larger, longer in body, leg, and neck, and rather plain in the head. They lacked the compactness, short leg, and early maturing qualities of North American cattle. The type of cow, however, was similar to that seen in the United States. Uruguay was visited during a period of drought and many of the cattle were very thin. It was noticeable, however, that the compact, deep-bodied animals withstood the drought much better than the rangy type. This fact, together with the earlier maturing qualities and greater hardiness which usually enable North American cattle to withstand the tick fever with fewer losses is causing many Uruguayan breeders to look to the United States for their breeding stock.

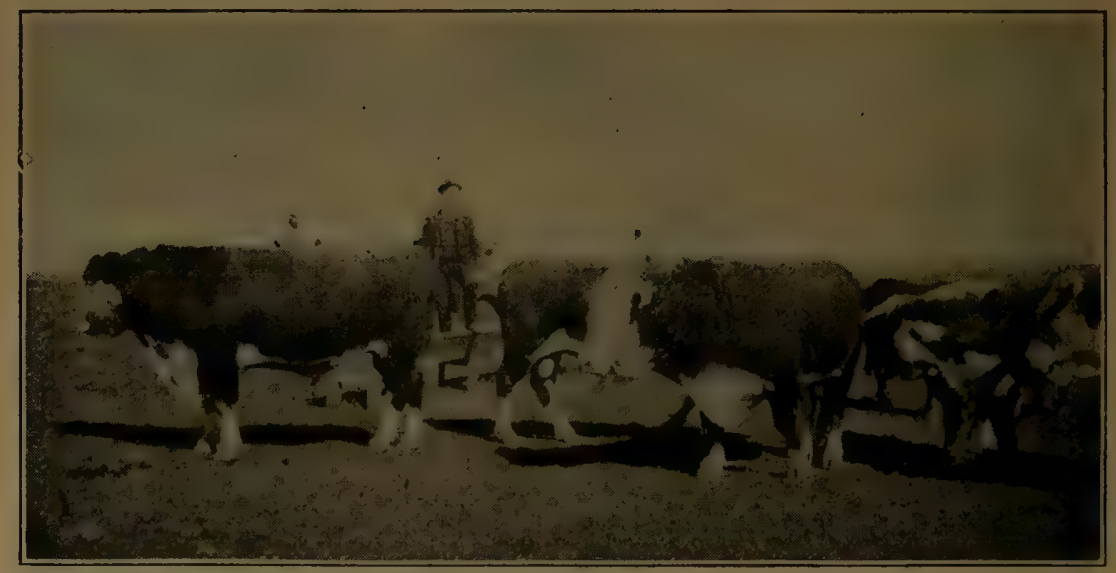

Fig. 6.-Purebred Hereford bulls on a ranch near Paysandu, Uruguay. This type sells for good prices in southern Brazil.

A good many ranchmen own a herd of pure-bred cattle and some own several. In addition they usually have a herd of high-class grade animals, which are really pure bred but can not be registered, and frequently another herd of lower grade animals from which steers are produced. If the bulls from the high-grade herd are well marked they are given extra attention and sold into Brazil for breeding purposes.

According to information obtainable, these "camp" or range bulls, when immune to tick fever, sold at about the following prices in 1919: Herefords, $\$ 400$ to $\$ 500$ each; Shorthorns, $\$ 300$ to $\$ 400$; Aberdeen Angus, about $\$ 250$ each. Since that time there has been a great reduction in price.

Both American and English bred cattle were seen on a few ranches. These places were visited in the spring after a rather severe winter, and almost invariably the American-bred cattle were in better 
flesh than the English animals found in the same pasture. Several ranchmen expressed a preference for American-bred bulls. Some of them seem to have had the impression that the English-type bull is more desirable because it is larger, but they are learning that the compact, short-legged American animal is very heavy in proportion to its appearance.

It seems probable that crossing native cows with American-bred bulls would produce an animal that would mature earlier and feed better through the winter.

At present tick fever and the foot-and-mouth disease are the two greatest problems facing the breeder in Uruguay. Many breeders in that country believe that the presence of the tick is not entirely a misfortune, because their principal market is in Brazil, which

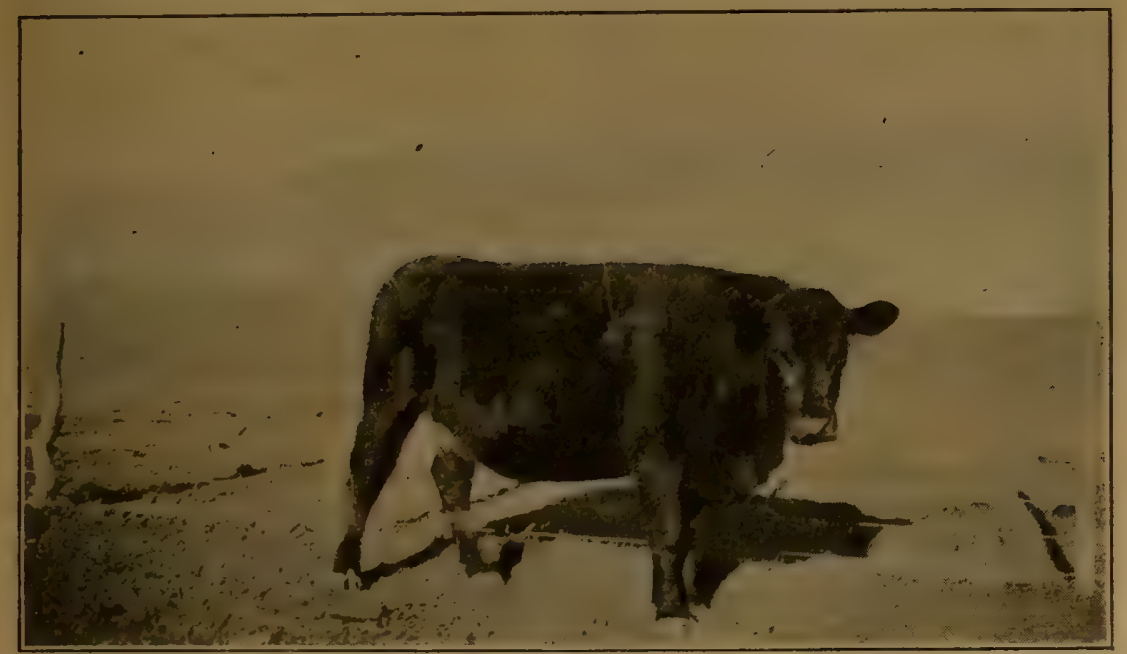

FIG. 7-Angus heifer on a ranch near Salto, Uruguay.

is a tick country, and in order to dispose of their bulls profitably the stock must be immune to tick fever.

Almost all of the southern half of Uruguay is tick-free territory, and some breeders have ranches in both the northern and southern parts of the country. Some breeders think it desirable to have the calves dropped in the tick territory, because the loss is very small when the animals are infected as calves. Other breeders produce their sale bulls in the tick-free territory and give them especially good care for the first year in order that they may get as much growth as possible, then take them to another ranch in the tick section, where they are immunized and sold. A small number die when handled in this way, but the loss is probably not so great as it is when the breeding herd is maintained in the tick section. $105982-22-3$ 
Different methods of immunizing cattle are used, but the most satisfactory seems to be that of taking the animal, when 12 to 20 months old, into the tick territory and allowing a few ticks to infect it. If too many ticks adhere to the animal it is dipped and allowed to become infected again. After the animal contracts the fever it is given the best possible care. It is claimed that by this method losses are reduced to a minimum.

It does not seem advisable to send cattle over 2 years of age from the United States into the tick territory of Uruguay. It is believed, however, if special care is given at the proper time, that North Amer-

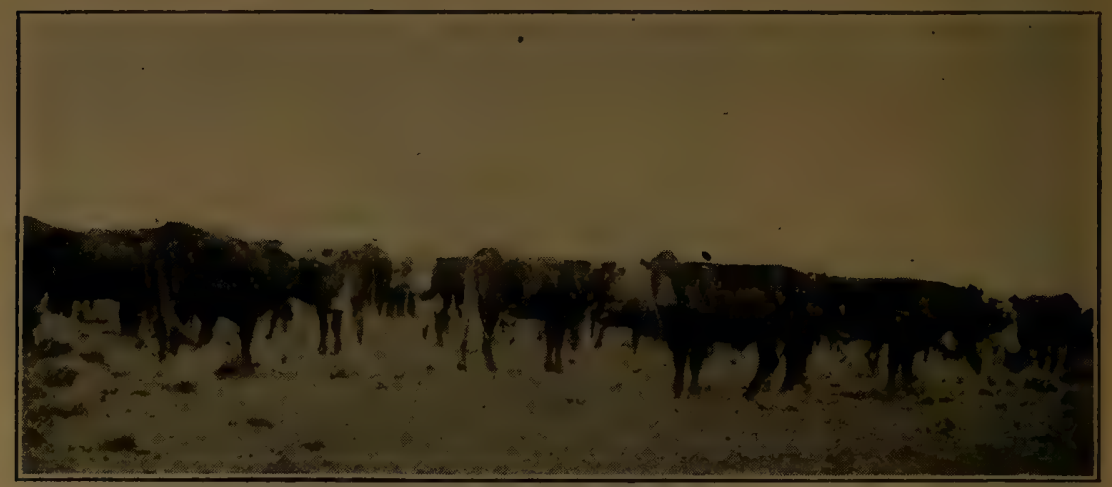

Fic. 8. - Steers on a ranch in Uruguay.

ican pasture-raised cattle under two years of age will go through this fever with very small loss. In 1920 a shipment of 165 cattle was. sent to Uruguay from the United States and at least 52 of them were sent into the tick regions. One breeder who received 30 lost 2; two others who received 6 each escaped loss entirely, and another who received 10 lost 4. The latter also imported 12 from England and lost all but one.

Foot-and-mouth disease is also a great menace to the live-stock industry in Uruguay. It occurs once and sometimes twice each year. Sometimes it is very light and comes at a time when the calves are large enough to go through it with only slight loss. Of course this disease always causes considerable loss in flesh, but, since the cattle fatten quickly on the cheap grass, the loss is not considered serious. On the other hand, if the disease comes at calving time or just before a sale or show, when the animals have been given extra attention and high-priced feed for a consideruble time, the loss is heavy.

- Despite these adverse conditions, however, the Uruguayan stockman is making a great success of his business. At one ranch 1,400 3 and 4 year old steers were sold for approximately $\$ 83$ per head, the owner stating that they represented a net profit of $\$ 55$ each. 
DAIRYING.

Specialized dairying has not been developed to any great extent, but since conditions are such as to make it a profitable business, it will doubtless become more important as the population increases. A few Holstein-Friesians have been imported from the United States and the Netherlands and are giving splendid results. Jerseys, Guernseys, and Ayrshires, are not used extensively.

In Uruguay it is a common practice to milk only once each day. The calf is separated from its mother in the evening and in the morning a part of the milk is taken from the cow, after which the calf is returned to its mother and allowed to remain the rest of the day.

\section{SHEEP RAISING.}

The sheep industry is very important in Uruguay. The sheep graze on the pastures with cattle. On some ranches it is estimated that the wool clip, lamb crop, and increase in weight of the wethers, practically pay the running expenses of the ranch, leaving returns from the cattle operations as net profit.

The most popular breeds are the Lincoln and Romney Marsh, with a few Shropshires, Hampshires, and Rambouillets. The Lincoln

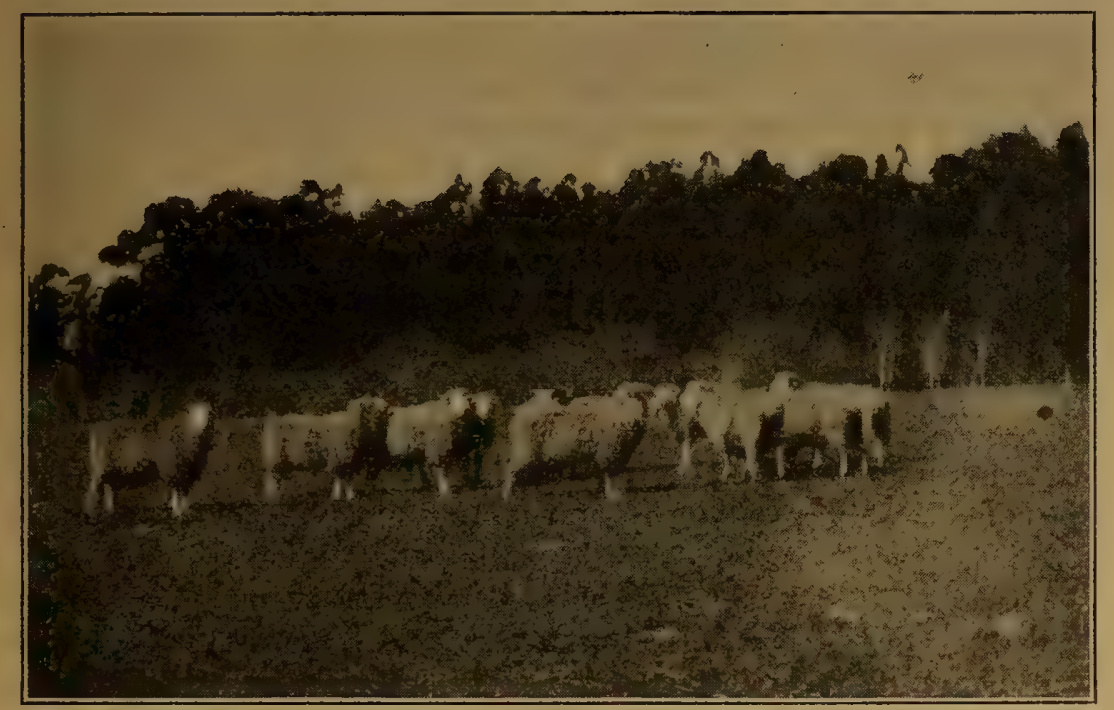

Frg. 9.-Breed and type of rams commoniy used in Uruguay.

and Romney Marsh are preferred because they graze satisfactorily with cattle, are of the large, hardy mutton type, and with a little attention raise about 85 per cent of the lambs dropped each year. Both breeds, however, produce rather coarse wool. Since the price of coarse wool has been very low for some time, some ranchmen have 
been crossing their coarse-wool ewes with Rambouillet and Merino rams in order to produce a finer fleece. This has already caused cansiderable demand for Rambouillet rams, and it seems probable that this demand will increase. Sheep as well as cattle are affected by foot-and-mouth disease, but losses among sheep are seldom so great as in the case of cattle.

THE HORSE INDUSTRY.

The horse industry is confined largely to the native breed, which is very similar to our western range horse. This type of horse weighs about 700 pounds, has great stamina, and is used almost exclusively for riding. Some of the more progressive breeders have imported Percherons, Clydesdales, Shires, and Suffolks from France and England, and have for some time been breeding a number of large horses. The lack of demand for heavy horses has prevented the draft breeds from becoming very popular.

\section{EXHIBITS AND SALES.}

There are two principal live-stock shows in Uruguay, the National Live Stock and Poultry Exposition at Montevideo, and the Live Stock and Poultry Exposition at Salto, which is situated in the northwestern part of the Republic.

The exposition at Montevideo is managed by the Rural Society of Uruguay and is almost exclusively a cattle show. This show was not a large one in 1920 ; less than 300 head of cattle, about 85 sheep, and 50 hogs were exhibited. Of the sheep about 60 were Lincolns and Romney Marsh and the others Merinos. There were a few horses, one a purebred Shire stallion, and the remainder saddle and road horses. The poultry exhibition was very good and most of the breeds found at shows in the United States were represented. The buildings are fine, large structures of brick and stone. They are built primarily for the purpose of housing cattle, sheep, and horses, no provision being made for hogs. The hogs on exhibition at the 1920 shows were placed in the sheep pens.

The Salto exhibition is also largely a cattle show. There were, however, about 350 head of sheep on the grounds, most of which were Lincoln and Romney Marsh, with a few Merino and Rambouillet rams. About 400 pure-bred bulls and cows and approximately 1,000 range bulls were shown. Probably about 75 per cent of these cattle were Herefords and most of the others were Shorthorns, with only a few Angus. Many ranchmen from southern Brazil go to the Salto show to buy their "camp" bulls. Sales of these "camp" bulls at Salto during the 1919 exposition amounted to something like $\$ 1,000,000$. At the 1920 exposition trade was slow, because of 
the effect of drought and the depreciation in ralue of South American money.

The judges furnished each year by the English Royal Society for the Argentine International Live-stock Exposition at Buenos Aires aiso place the animals at the Uruguayan shows. The awards are all made before the formal opening. The cattle are shown in a large open arena from which the public is barred. No one is allowed in this inclosure during the judging except the herdsmen holding the cattle, the judge, and the clerk. This plan enables the judge to arrive at his decision unhindered. On the other hand, the public is denied a close-up view of the animals while they are being placed, thereby limiting to a certain extent the educational value which might be derired from watching the expert judges at work. The most serious fault noted in a very large number of the cattle shown was their crooked, weak, faulty hind legs.

The champion and reserve champion Shorthorn heifer calves were fitted by a Kansas man who went to South America with the first shipment of cattle from the United States to Uruguay. These two calves were strictly North American type and well fitted. It is believed that they would have compared well with those exhibited at the 1920 International Live-Stock Exposition at Chicago.

The general system of selling breeding animals in Uruguay is at public auction either at sale barns or at the exposition grounds. Auction sale barns are located at Montevideo and other cities in the country. Both pure-bred and "camp" bulls are sold at a few of these barns. It is customary for ranchmen and farmers to go to these centers in August and September to purchase their breeding stock. The sales are conducted in much the same way as sales of pure-bred cattle in the United States, except that the auctioneer cries the bid he has instead of the one he wants. The auctioneer sells on a commission basis, the commission being paid by the purchaser.

The sales held at the exposition grounds in 1920 were not so good as many of the breeders expected, although a number of bulls brought $\$ 2,800$ to $\$ 3,738$, expressed in terms of United States currency. The highest price paid was $\$ 8,411$ for an American-type bull which ranked ninth in his class. In many instances bulls of rery inferior type and individuality sold for much more than they would have brought in the United States. Herefords sold for better prices generally than any other breed.

A few sales of imported Herefords were attended and those from England sold especially rell. In one sale, 50 animals sold at an average of more than $\$ 3,740$ and the top price $\pi$ as $\$ 18,690$. In another sale the top price was $\$ 25,233$. Most of the bulls in these two sales were very large, rough, 3-year-olds, and those in the firstmentioned sale especially were very fat. 


\section{POSSIBILITIES OF' DEVELOPING TRADE.}

Many breeders are of the opinion that considerable trade will develop between the United States and Uruguay when the rate of exchange returns to normal, especially if the cattle can be immunized. Uruguayan live-stock breeders seem to be especially alert regarding their business and are striving continually to improve their herds. They have excellent stock and doubtless will continue to sell a large number of breeding animals into Brazil. Just now the demand appears to be for Hereford, Shorthorn, and Aberdeen Angus cattle, a few Poland China and Duroc-Jersey hogs, and Rambouillet rams. If the people begin farming more extensively there may be a small demand for heavy horses, but probably not for some time yet.

It is very doubtful whether many breeders will come to the United States to buy their stock. European countries make it a practice to take their stock to Montevideo for sale. Under this arrangement it is comparatively easy for the Uruguayan breeder to visit the auctions and select his stock. Naturally he would much rather make his purchases in this way than to buy from the United States and spend considerable money and time in getting the animals home, even if the stock obtained is not quite so good. For this reason it may be necessary in the development of trade between the United States and Uruguay to send animals to that country to be sold at auction. Only animals that are in good flesh should be shipped.

Those who are interested in the development of a permanent livestock trade with Uruguay should consider carefully all the details relative to the exportation of live stock to that country, especially the difference in the rate of exchange. It is also advisable to consult some reliable auction firm or dealer in Uruguay before shipments are made. It is doubtful whether hogs or sheep should be sent into Uruguay except on order. There is only a limited demand for them, and any one sending such stock to be sold at auction may easily be disappointed with the returns. It is possible that in a few years the demand may increase to such an extent that consignment sales will be justified.

Before any animals are shipped careful inquiry should be made relative to the latest regulations, including quarantine, export papers, pedigrees, transfers, and the method of signing and legalizing all documents. The Uruguayan Government requires a quarantine period of 30 days for cattle and 15 dars for sheep and hogs immediately after unloading. Before leaving the United States all breeding cattle must be tested for tuberculosis by a Government official. Hogs should be tuberculin tested and immunized against cholera for the protection of the shipper. The Uruguayan and Argentine Governments will not accept a test certificate from other countries, but make their own tests of all cattle and hogs coming into the country. 


\section{BRAZIL ${ }^{1}$}

Brazil is about as large as the United States and has a wide variation in soil and climate. With the exception of a few sections in Rio de Janeiro, Sao Paulo, and Minas Geraes, the country resembles the mountainous regions of southern Missouri. In Rio Grande do Sul, Sao Paulo, and Matto Grosso there are wide stretches of prairie land similar to the rolling country of northern Missouri. In the mountainous regions a large part of the land is covered with either grass or timber. It is too rough to be cultivated successfully. The deep, red clay loam in the central and southern part of Brazil appears to be very fertile.

Transportation facilities, except in a part of the States of Sao Paulo and Rio de Janeiro, are very poor. On most of the railroads there are only two or three trains a week. This makes it necessary

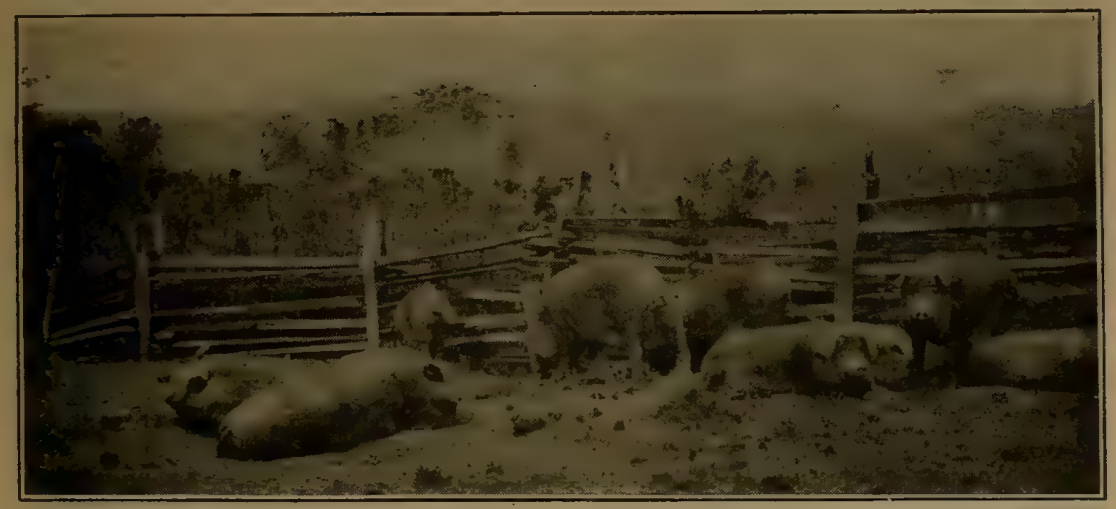

FIG. 10.-These hogs had been driven 50 miles on the way to market. They average about 3 miles a day. Faxina, Brazil.

to drive live stock long distances to market or loading points. Until recently wagon roads were very poor, and they are still limited in number, but during the last few years marked improvements have been made. Many Brazilian landowners now own automobiles and are becoming more interested in good roads. Oxen are used almost exclusively for hauling farm products to market.

The States of Rio Grande do Sul, Parana, Santa Catharina, Sao Paulo, Minas Geraes, Rio de Janeiro, Goyaz, and Matto Grosso constitute the principal live-stock sections of the country. In all of the cleared sections there seems to be an abundance of natural grass, which furnishes good grazing for cattle. Much less labor is involved in the production of live stock than in growing grain, and as long as the country remains sparsely populated the people will be

1 This report covers the southern and eastern parts of Brazil, or the States of Rio Grande do Sul, Parana, Santa Catharina, Sao Paulo, Minas Geraes, and Rio de Janeiro. 
able to obtain a satisfactory income from live stock alone. When the population increases they will doubtless farm their land more intensively.

The principal feed crops produced are corn, mandioca, and sugar cane. Mandioca is a root crop that supplies an abundance of fattening feed for hogs and yields heavily without cultivation. Grains are grown only in a limited way, in spite of the fact that the climate and distribution and amount of rainfall are favorable for the production of abundant crops. Wheat, corn, and oats are grown in small patches among the stumps and practically no machinery is used. The land is seldom plowed or the crops cultivated. A sharp stick is used in planting corn. After the corn matures hogs are frequently

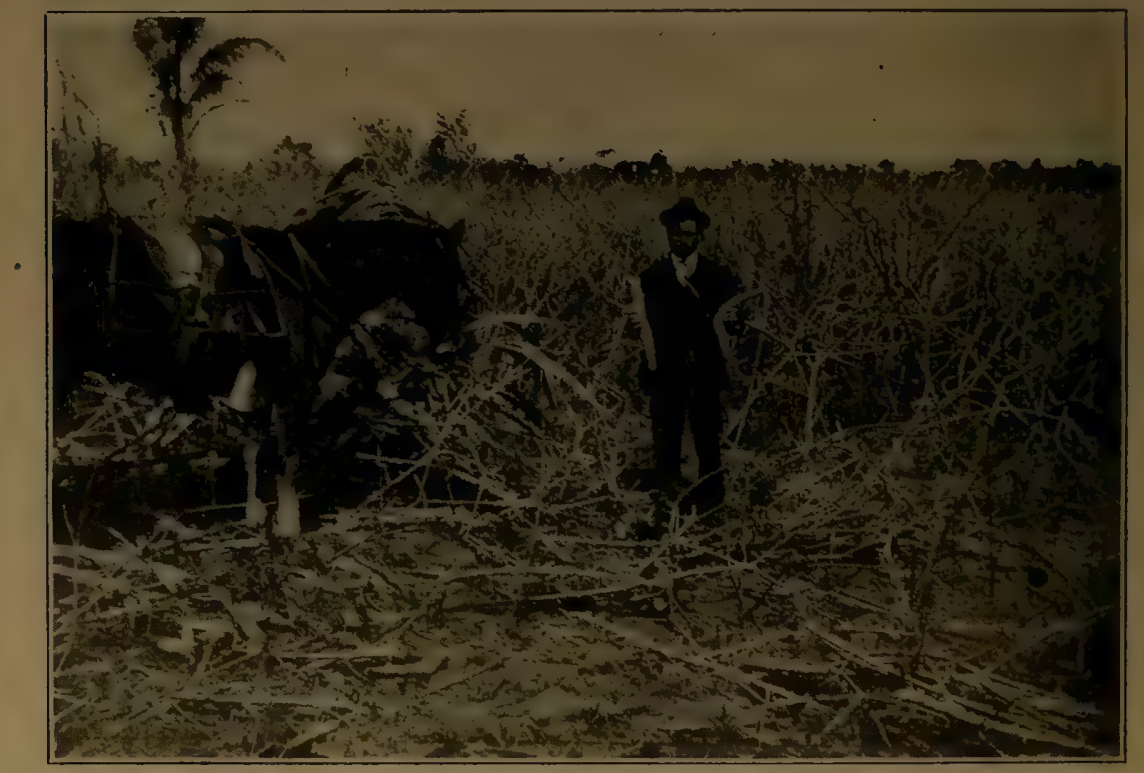

Fic. 11. - $\Delta$ Mandioca field in Brazil.

turned into the field to harrest the crop. A yield of 25 to 40 bushels of corn to the acre is not uncommon.

\section{THE PRESENT LIVE-STOCK INDUSTRY.}

The cattle and hogs of Brazil resemble somewhat the native types of southern and eastern Texas. However, a good many well-bred animals were found in every section, and many producers have apparently been attempting to breed an animal which is adapted to local conditions and which will yield a more satisfactory carcass than does the native type.

Brazil has comparatively few breeders of pure-bred live stock, but there seems to be an increasing interest in better bred animals. 
Many of the larger coffee plantation owners are raising some live stock and some of them are beginning to establish herds of purebred cattle and hogs.

\section{CATTLE RAISING.}

The breeds of cattle which seem to give best results in Brazil are the Hereford, Shorthorn, Angus, Caracu or native, Holstein, and Zebu, which is an East Indian breed. Herefords and Shorthorns are imported largely from Uruguay, Argentina, and England; Holsteins from the United States and the Netherlands; and Zebus from East India. The Caracu is very similar in type to the best beef cattle in the United States and seems to be able to withśtand ticks and drought as well as the Zebu. The Zebu is a hardy animal which is

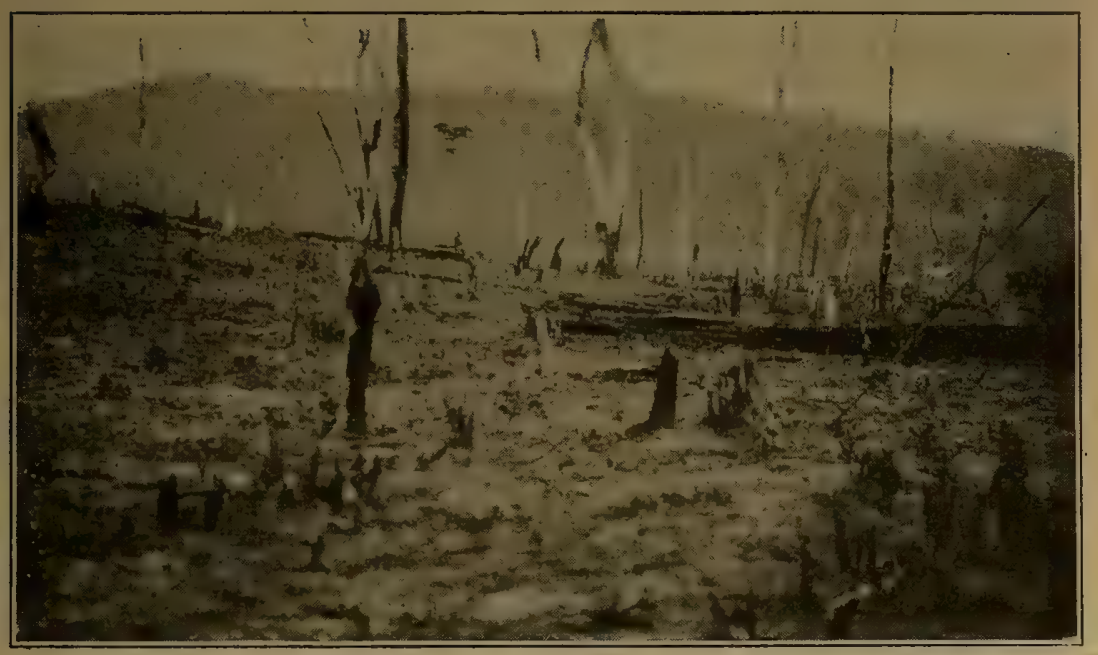

FIG. 12.-A field as it is usually prepared for corn in Brazil.

generally used throughout Brazil and is being imported in large numbers. It withstands tick fever, the berne fly, and shortage of feed especially well, requires only a small amount of attention, and sires a high percentage of calves. Many Brazilians consider the production of a large number of calves much more important than the production of animals of superior type and quality. However, they are now recognizing the tendency of the Zebu bull to produce an animal which yields an inferior grade of beef when slaughtered

The cattle tick, berne fly (also known as warbles), and foot-andmouth disease must all be contended with in cattle raising. Perhaps the greatest drawback to the industry is the tick, which causes a fever and is constantly sucking blood from the animal. The Department of Agriculture of Brazil has succeeded in finding a method of immunizing cattle under two years of age against this 
fever. If the method can be further perfected so that losses are practically eliminated, large numbers of Herefords, Angus, Shorthorns, and Holsteins will doubtless be imported into Brazil. There

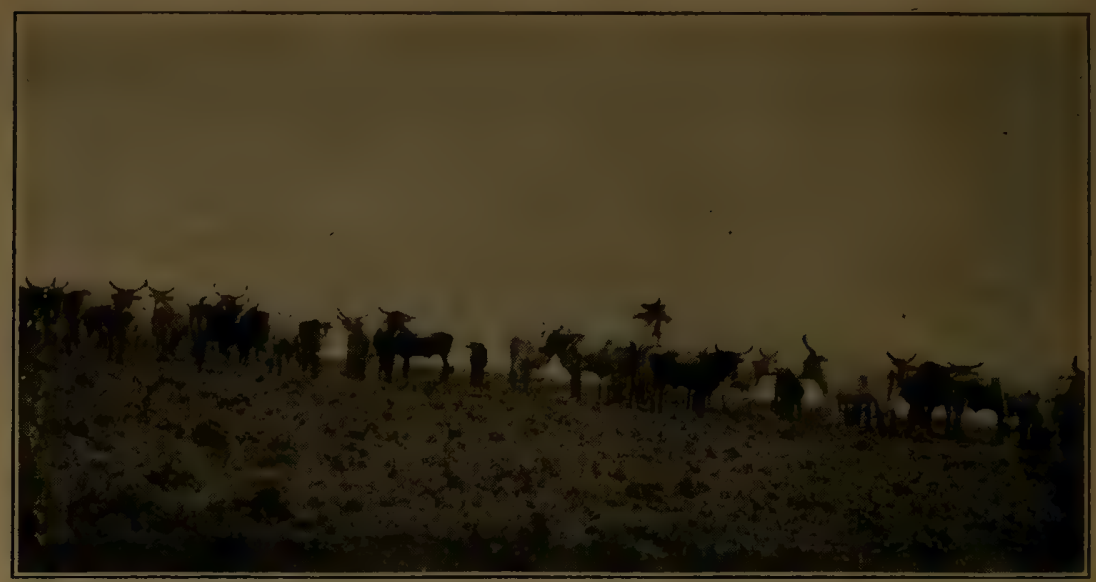

FIG. 13. - Native steers on a range in central Brazil.

has been considerable discussion regarding an attempt to eradicate the tick from Brazil, but so large an undertaking would cost a great amount of money and it is doubtful whether it will be done soon.

The berne fly is a very severe pest, especially in the central part of Brazil. Large masses of these worm-like insects collect under the skin on the shoulders and back of an animal; in the spring of the

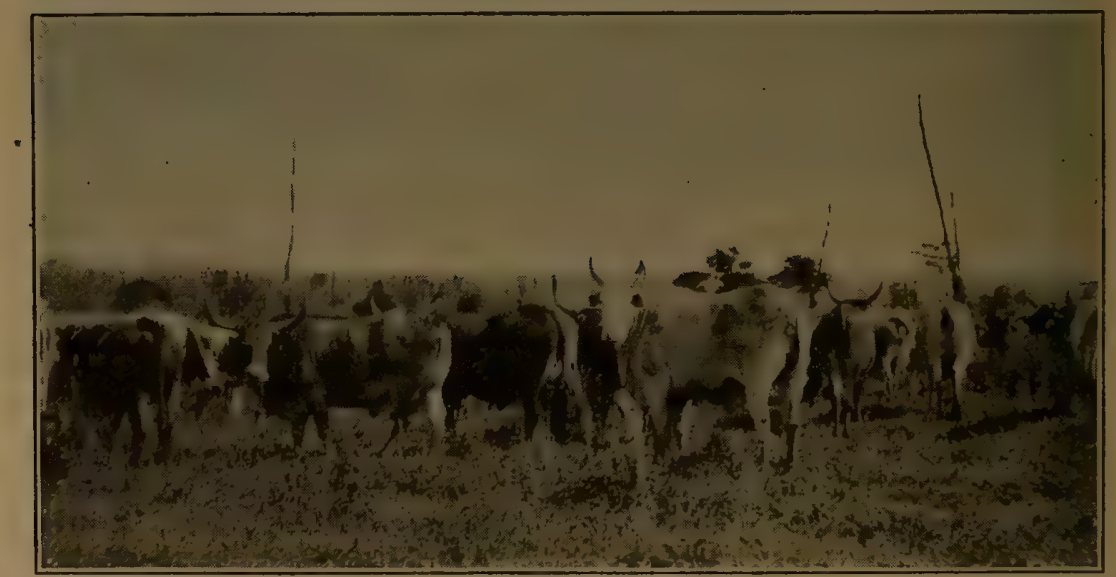

FIG. 14.-Caracu steers on pasture of Gordura grass, Barretos, Brazil.

year they come out, causing the animal much annoyance and injuring the skin so that when the animal is slaughtered the hide is of very low grade. 
The manner in which live stock is handled in Brazil makes a strong, rugged constitution essential. Oftentimes imported bulls, turned out with the herd where they have to rustle for their feed, receive little care. Under these conditions they frequently do not give the best results. It was observed that when imported bulls were given a fair chance, kept away from the cows part of the time, and dipped at frequent intervals, they remained in good condition and sired just as many calves as the Zebu bulls.

A number of conditions should be considered in undertaking the development of an export cattle trade with Brazil. A permanent trade can not be established unless the animals purchased by Brazilian farmers will live and give good results. The hot climate, lack of

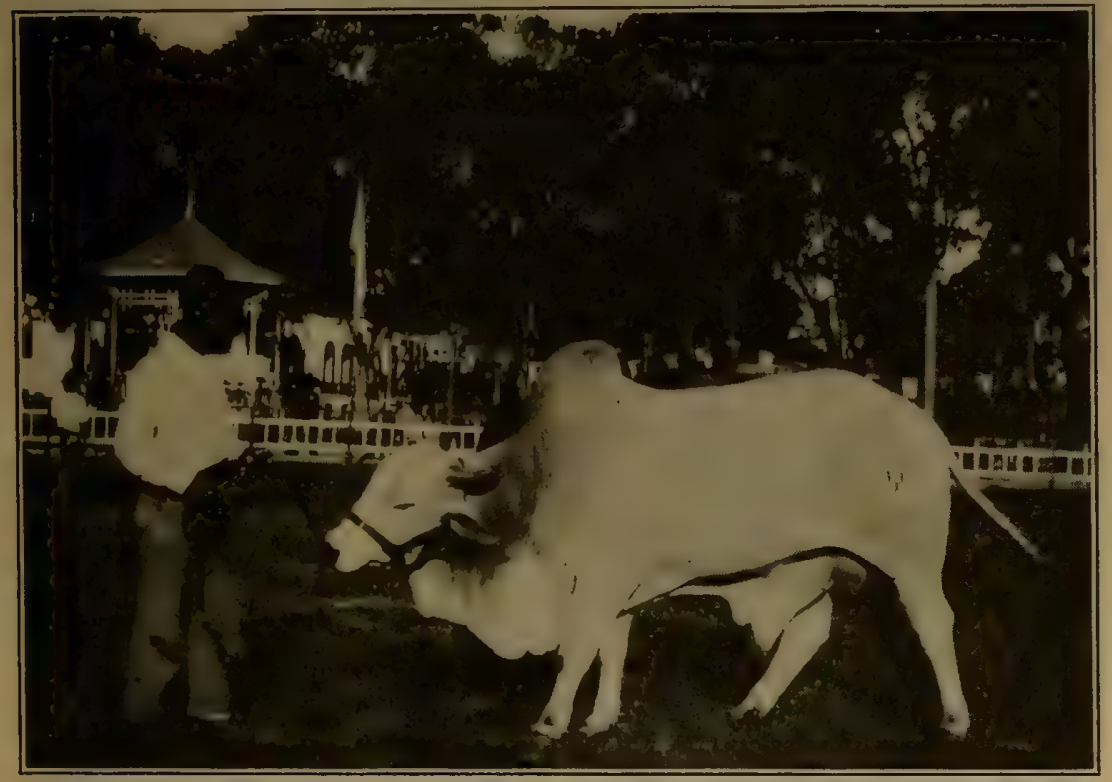

Frg, 15. A Zebu bull shown at the Live Stock Exposition at Rio de Janeiro, Brazil.

care, different kinds of grass, and prevalence of disease make thr life and productivity of imported bulls extremely uncertain. In the first place, all animals from the United States must pass through an attack of tick fever. Cattle must be under 2 years of age to live through this fever, and it is hard for such young animals to become accustomed to the change of feed and climate. Furthermore. the Zebu is well established among Brazilian cattle raisers and they are not inclined to discard it as long as steers sired by Zebu bull do not meet price discriminations on the market due to the inferior beef produced. Only a limited amount of Zebu meat can be exported, however, because Great Britain and European countries discriminate against it. Animals sired by Hereford, Angus, or Shorthorn bulls 
from the United States mature earlier and produce a good quality of beef. Breeders are sure to realize these facts sooner or later, and it is thought that in the future they will demand more bulls of improved beef-producing breeds. The Zebu will probably be used to give hardiness to the foundation stock, but imported bulls from the United States and other countries will be used to improve the type.
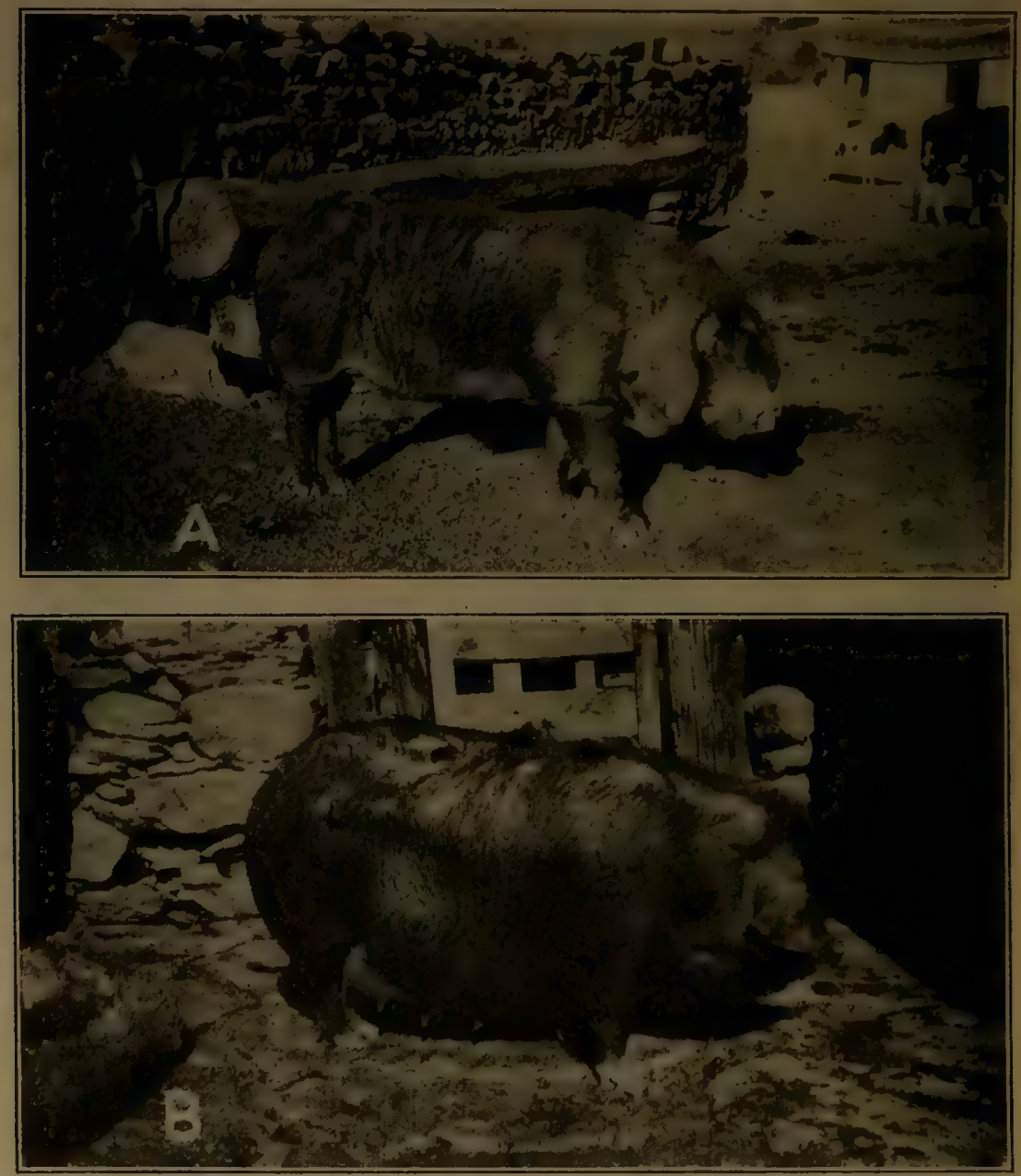

Fig. 16.-Types of the national breed of swine in Brazil.

HOG RAISING.

The leading breeds of hogs found in Brazil are the National (native) and Large Black, both of which resemble the large-type hog of the United States. They are rather coarse in quality, with low backs and poor feet, and are slow to mature. 
The common practice is to allow hogs to graze or rustle for a living in the timber for the first year and a half or two years. Then they are turned into a field of corn or put into a fattening pen to be fed for market. Corn is the principal feed used, and in the dairy sections it is supplemented by skimmed milk. Large numbers of hogs are marketed each year from the sections in which corn is grown successfully and which are located near the railroads.

Duroc-Jerseys and Poland Chinas imported from the United States are to be found on a very few farms. Most of the Duroc-Jerseys are of good quality and type and the Poland Chinas are of the smaller, medium type. They give good results and are becoming more and more popular each year. Berkshires, generally imported from England, are found in limited numbers. In view of the fact

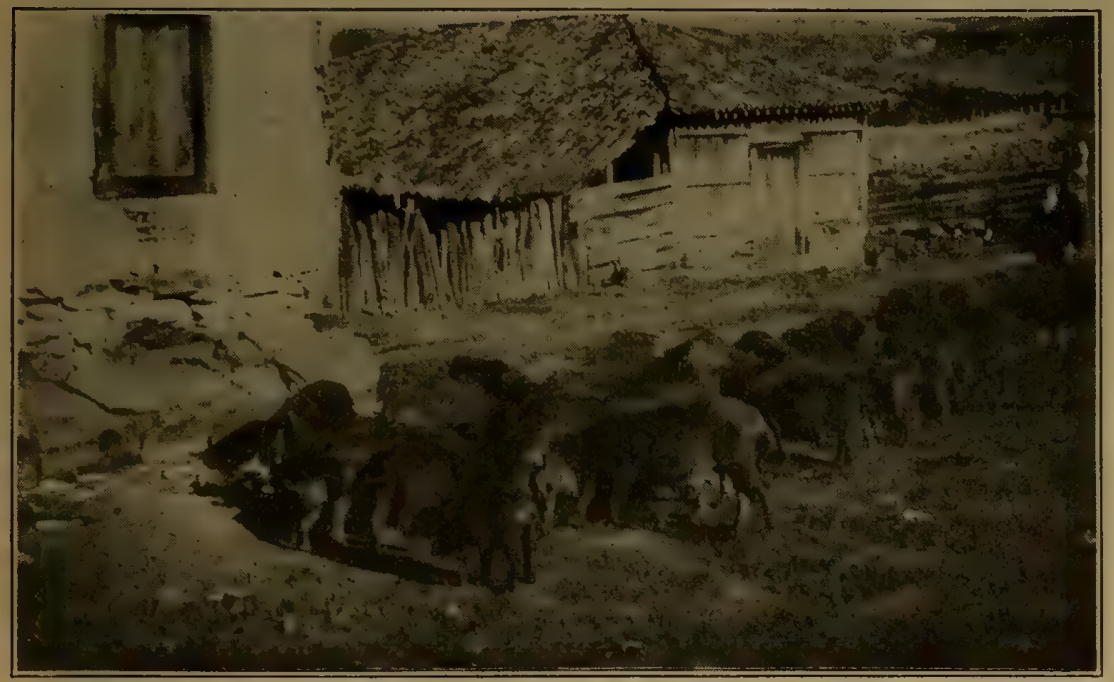

FIG. 17.-Hogs feeding on a ranch near Lavras, Minas Geraes, Brazil.

that the Brazilian farmer likes large-type hogs, it is believed that the modern type of large Poland China and Duroc-Jersey will meet with favor in Brazil. There seems to be no question but that the type and slow-maturing qualities of the native hog of Brazil could be greatly improved by crossing with boars of some of our earliermaturing breeds.

Hogs are liable to have cholera and foot-and-mouth disease. Cholera causes considerable loss in some sections, but it does not spread so rapidly as it does in the United States, because of the mountainous character of the country. Foot-and-mouth disease is also isolated to a certain extent by the same condition. Ordinarily the losses due to foot-and-mouth disease among hogs are not very great. However, if the disease appears just before or after farrowing the litter is frequently lost. 
It will probably be some time before any large number of hogs are sent from the United States to Brazil. There is, however, some demand for hogs of fairly good quality and this demand should increase from year to year.

\section{DAIRYING.}

The dairy business is confined largely to the States of Minas Geraes and Sao Paulo. In these two States large numbers of cows are milked and butter and chesse are manufactured in large quantities. However, the dairy business is not carried on in a modern way. Very seldom do the cows receive any feed except grass, and few up-to-date barns are used. Very few, if any, milk or butter-fat records are kept.

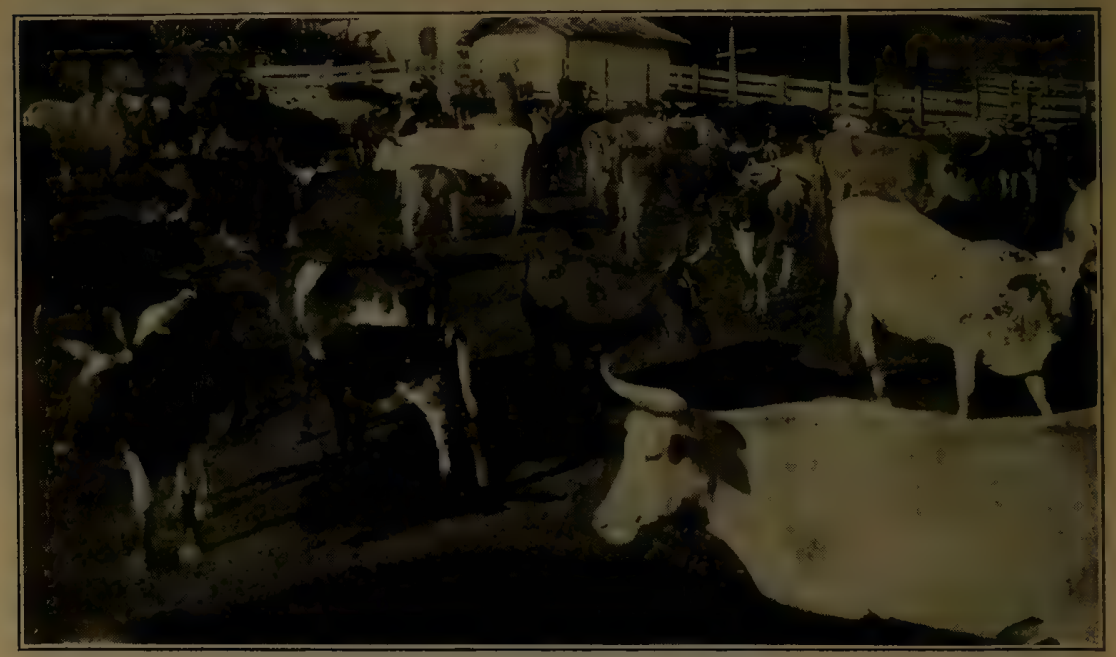

FIG. 18.-A dairy herd near Lavras, Minas Geraes, Brazil.

As in Argentina, the cows are commonly milked only once each day. Foot-and-mouth disease is a serious menace to the dairy industry because of the reduction or cessation of the milk flow incident to an attack of that disease.

\section{SUGGESTIONS FOR LIVE-STOCK EXPORTERS.}

The fundamental conditions upon which live-stock trade between the United States and Brazil will depend are: First, ability of our live stock to give good results there; second, the development of the agricultural resources of Brazil; third, normal financial conditions. The high cost of exportation, the rate of exchange, and the low prices that the Brazilian breeder is willing to pay are adverse influences at the present time, but, if the first three difficulties are overcome, it is believed that the others can be adjusted satisfactorily. All of these conditions make the development of trade with Brazil a some- 
what hazardous undertaking. Heavy risks must be assumed, especially in the early stages, but once proper connections are made and confidence is established among a large number of the Brazilian cattlemen, it seems probable that the trade will assume rather large proportions.

It is not advisable to send our highest class show cattle to Brazil at this time. Good, strong, heary-bodied animals, which are not too fine in quality yet in no way inferior, are best adapted to the Brazilian trade and should give good returns to the seller and good results to the buyer. A few cattle can be sold at the leading shows at fair prices, but exporters should not expect to receive very high

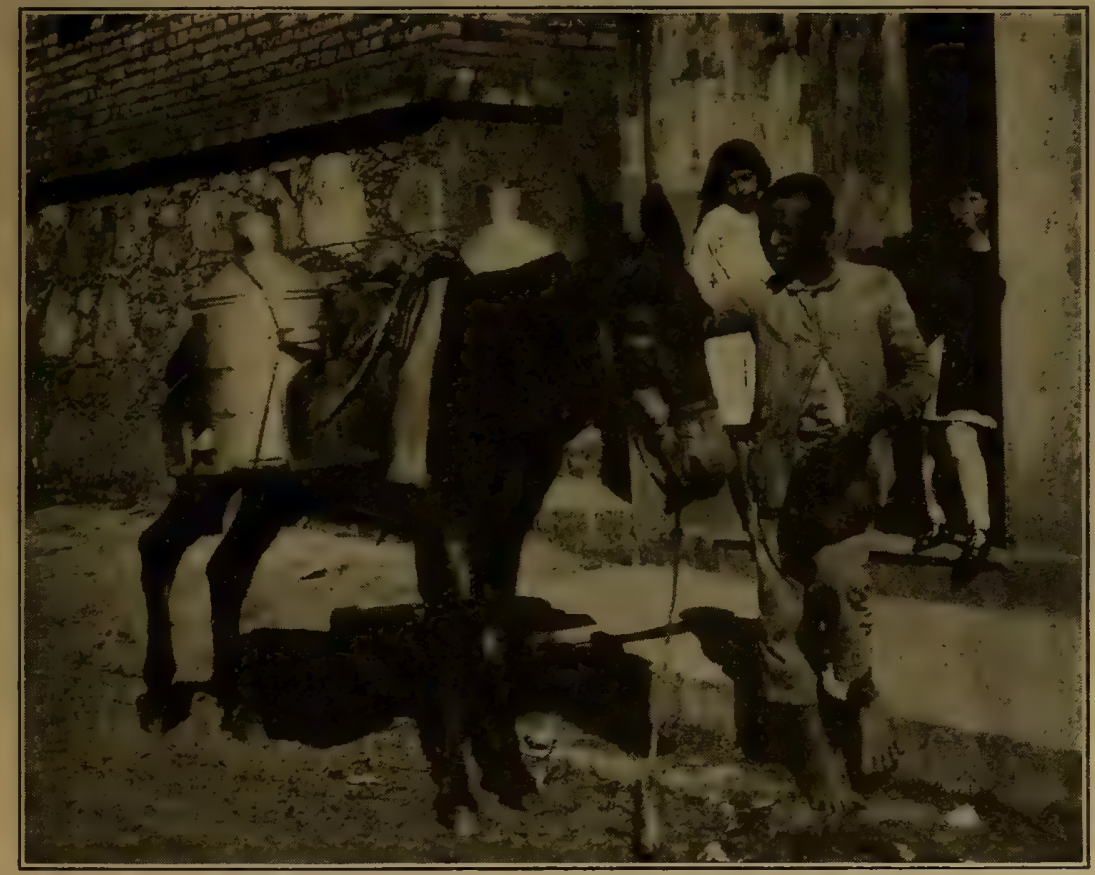

FIG. 19.-Delivering milk in Lavras, Minas Gereas.

prices until it has been proved that animals from the United States can withstand tick fever without a large percentage of loss. Although Brazilian cattlemen usually expect to lose part of the cattle they import, they are naturally disappointed when an animal dies. If cattle could be immunized before they are shipped and sold with a guaranty against tick fever, a substantial trade would develop more quickly. It is impossible to have young cattle appear in sale condition immediately following an attack of tick fever, and in Brazil, as well as in this country, live stock of any kind sells to a better advantage when fat. If the Brazilian breeder can be assured of good results, it is believed that he will be willing to pay very good 
prices for North American cattle. This opinion is based partly on a report that a Zebu bull imported from India brought $\$ 18,000$ and that an offer of $\$ 4,000$ was made to the owner of a yearling Holstein bull at the International Exposition at Rio de Janeiro in 1920.

Uruguayan breeders have sold large numbers of bulls to go into the southern part of Brazil, where they have been very successful. As yet they have not entered the central and western parts to any large extent. However, some Uruguayans have been planning to sell live-stock into the Matto Grosso country, the western grazing section of Brazil, and it is believed that they will be able to furnish cattle that will prove satisfactory there.

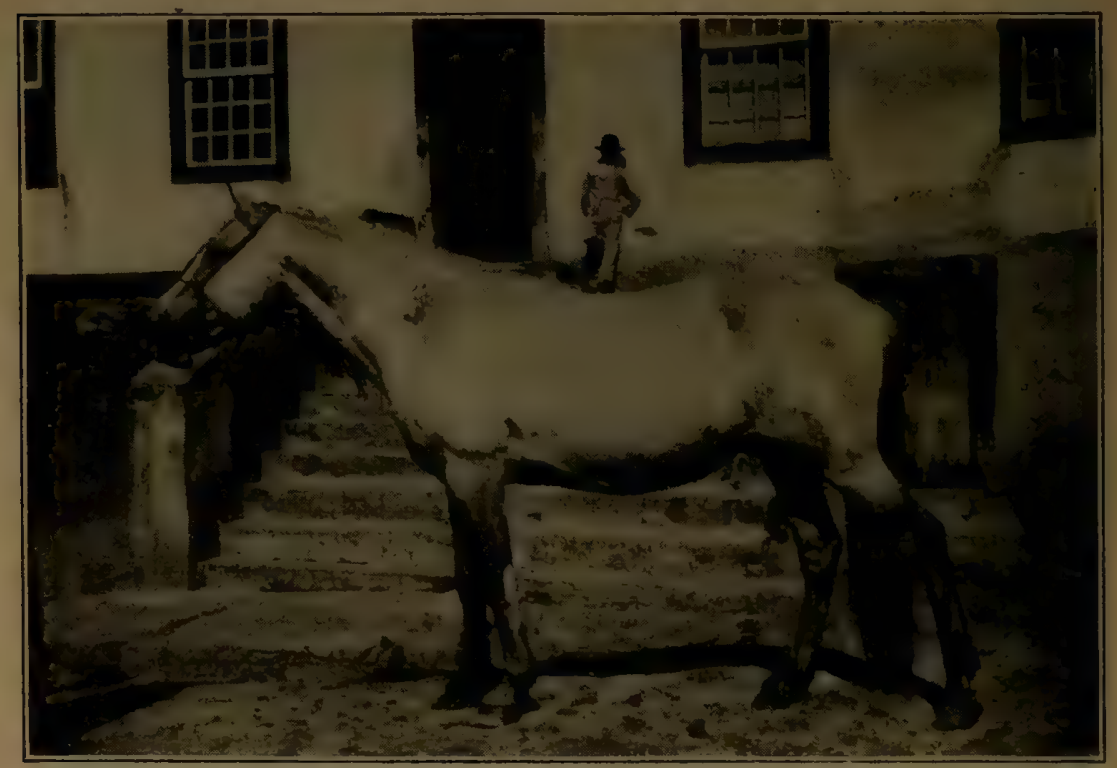

FIG. 20.-Type of stallion used in Brazil. Approximate weight, 800 pounds.

The low rate of exchange between South American countries and the ease with which breeders can obtain bulls from Uruguay and Argentina enables them to buy cattle there very much cheaper than from the United States. During the first few months of 1921 the rate of exchange was so much in favor of the United States that prices seemed unusually high to Brazilian breeders.' The conto, which is ordinarily worth $\$ 250$ in United States money, depreciated to such an extent that it was worth only $\$ 150$ in April, 1921. Although the prices of pure-bred live stock in the United States have fallen at least $33 \frac{1}{3}$ per cent since January, 1920, the Brazilian breeder is not now in a position to take advantage of it.

In spite of these unfavorable conditions, the Brazilian likes to trade with North Americans and will do so if he sees a fair chance of 
success. He is willing to pay reasonable prices, but with only a limited number of small pure-bred herds, it is quite natural that he is not yet ready to pay the high prices that well-established breeders in other countries are willing to pay. As soon as more pure-bred herds can be established it is believed that there will be a demand for good sires to improve the herds. It seems logical, however, that breeders will get the bulk of their foundation stock from Uruguay and Argentina.

The secretary of the rural society in Sao Paulo made the statement that during the next 10 or 12 years Brazil would require 10,000 bulls annually and was very enthusiastic about trade with the United States. It is believed that the firm or association which becomes well known during the early years of development will have a good future business.

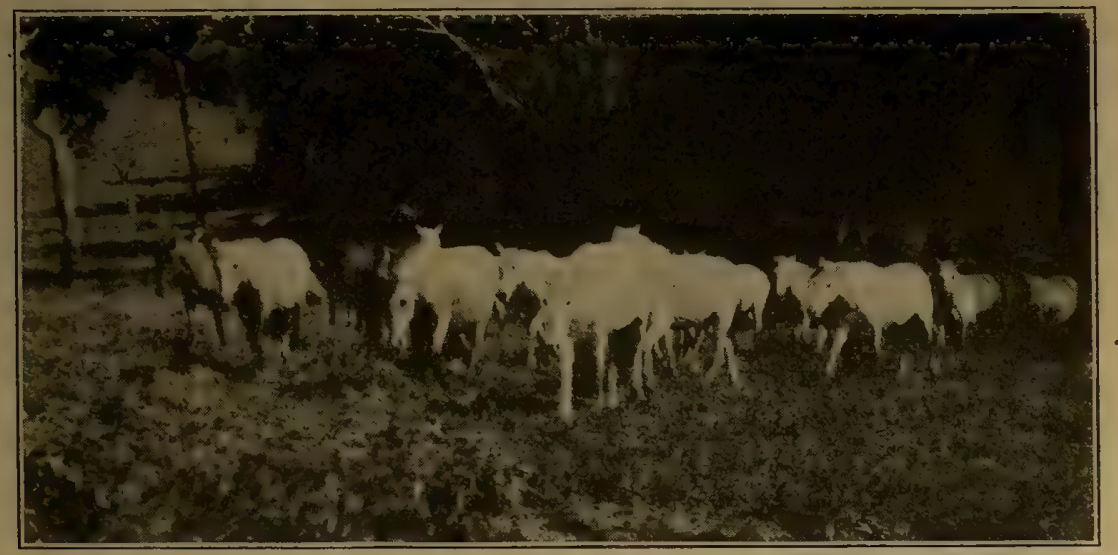

FIG. 21.-Types of mares used for breeding purposes in Brazil. Approximate weight, 700 pounds.

A rather limited demand for light horses to be used almost entirely for saddle purposes is apparent.

Most of the popular breeds of poultry found in the United States are used in Brazil. Prices for imported stock are not high. Until this trade is developed further it is thought that breeders would be unwise to send poultry except on order.

\section{CHILE.}

The agricultural district of Chile is a strip of territory about 30 miles wide and 600 miles long on the western side of the Andes Mountains and in the southern half of the country. The farms are about the size of those in the Corn Belt of the United-States.

While the live-stock business is one of the leading industries of Chile, it is not so extensive as that of Argentina, Uruguay, or Brazil. 


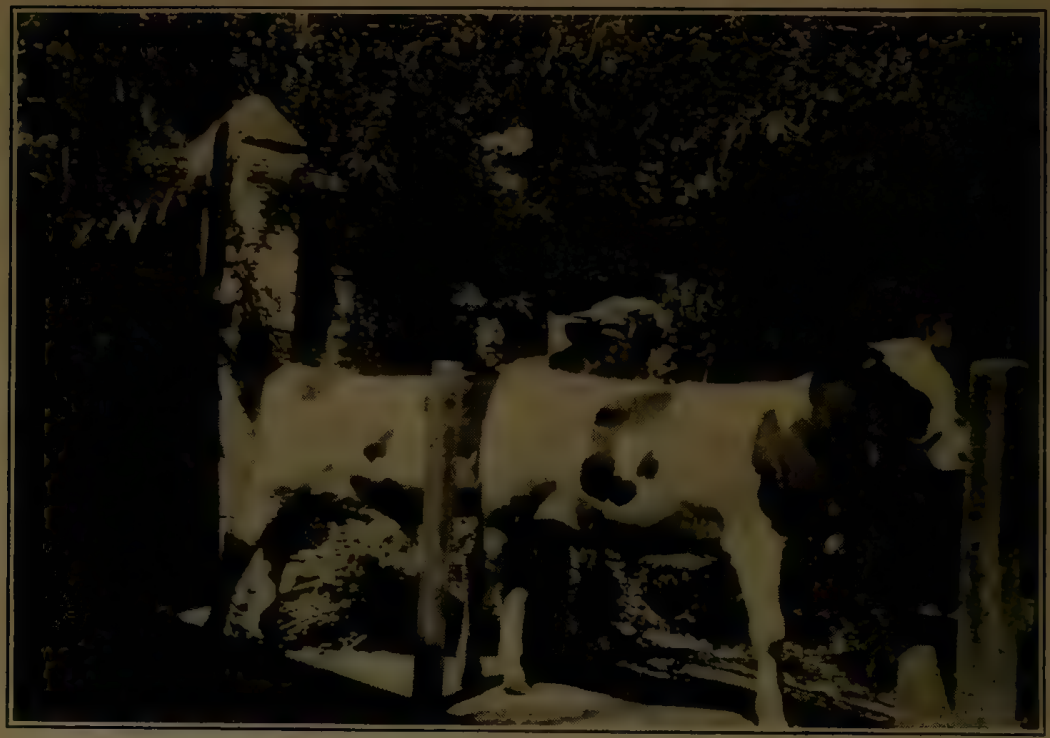

Fig. 22.-Twin bull calves, Santiago, Chile. The foundation stock was imported from the United States.

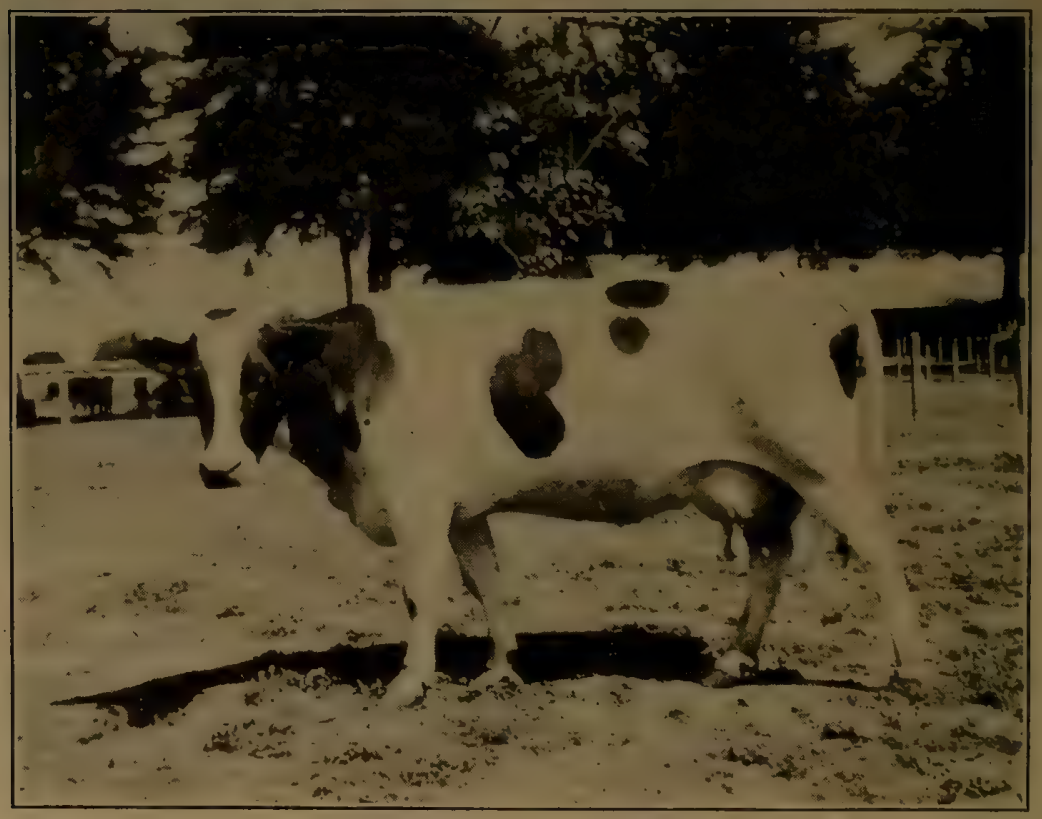

FrG. 23.-Type of cow found in a dairy herd near Santiago, Chile. 
The feed crops are corn, barley, oats, wheat, root crops, alfalfa, and clover.

The Shorthorn breed of cattle is most common and shows very good quality and type. The dairy industry is growing rapidly near the larger cities and the Holstein breed is the most popular. One of the best dairy herds in all South America was visited in Santiago, Chile. Silos and up-to-date equipment of all kinds were being installed on the farm. A large number of the cattle in that herd had been imported from the United States and were giving excellent results.

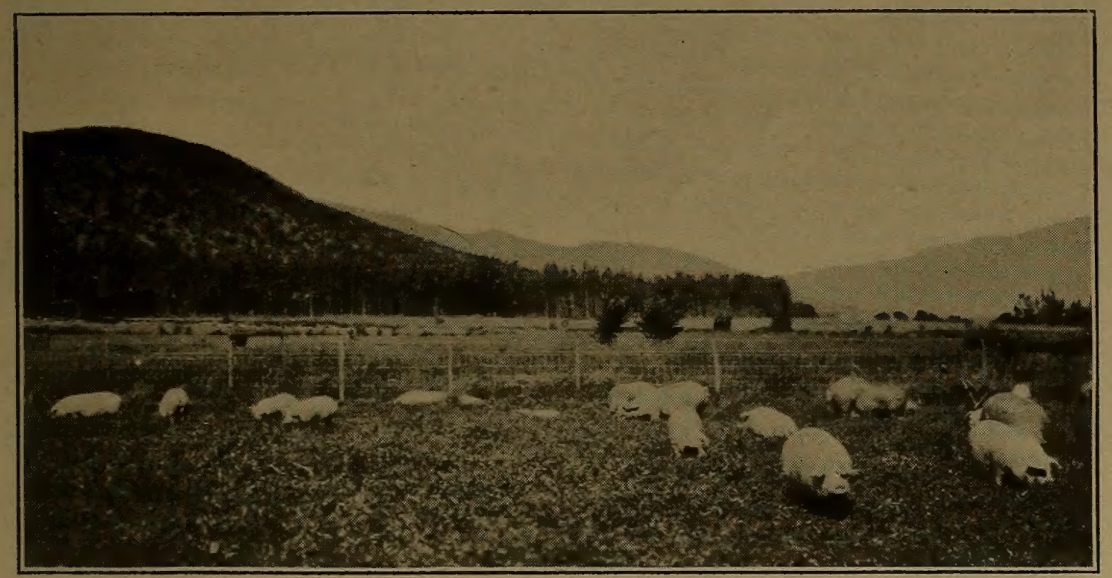

FIG. 24.-Purebred Chester White hogs grazing on clover near Santiago, Chile.

Swine production is carried on only in a limited way, but shows promise of great development. Hogs imported from the United States were apparently doing about as well as they do here.

It is believed that a limited demand can be developed for Shorthorn and Holstein cattle and for Duroc-Jersey, Poland China, Chester White, and possibly other breeds of hogs, but the quality must be good. During the latter part of 1920 and the first half of 1921 the rate of exchange between Chile and the United States was too much in favor of the United States to permit a very large live-stock trade. 


\section{ORGANIZATION OF THE UNITED STATES DEPARTMENT OF AGRICULTURE.}

Secretary of Agriculture. Assistant Secretary

Director of Scientific Work

Director of Regulatory Work.

Weather Bureau.

Bureau of Agricultural Economics.

Bureau of Animal Industry.

Bureau of Plant Industry.

Forest Service

Bureau of Chemistry

Bureau of Soils.

Bureau of Entomology

Bureau of Biological Survey

Bureau of Public Roads

Fixed Nitrogen Research Laboratory

Division of Accounts and Disbursements

Division of Publications

Library

States Relations Service.

Federal Horticultural Board

Insecticide and Fungicide Board

Packers and Stockyards Administrution

Grain Future Trading Act Administration-\}

Office of the Solicitor.
Henry C. Watuace.

C. W. Pugslet.

E. D. BAIL.

Charles F. Marvin, Chief

Henry C. Taylor, Chief.

JOHN R. MOHLER, Chief.

William A. Taylor, Chiế.

W. B. Greeery, Chief.

Walter G. CampbeLl, Acting

Chief.

Murton Whitney, Chief.

L. O. Howard, Chief.

E. W. Nelson, Chief.

Thomas H. MacDonam, Chief.

E. G. Cotrrell, Director:

A. Zappone, Chief.

JoHN L. CoBBs, Jr., Chief.

Claribel R. Barnett, librarian.

A. C. True, Director.

C. L. MARLATT, Chairman.

J. K. HaYwoon, Chairman.

Chester Morritu, Assistant to the secretary.

R. W. Wuritams, Solicitor:

This bulletin is a joint contribution fromi-

Bureau of Agricultural Economics, H. C. TAYloR, Chief

Division of Livestock, Meats, and Wool, O. V. WHALIN, in charge.

Bureau of Animal Industry, JokN R. MoHLen, Chief.

Division of Animal Husbandry, D. A. SPENCER, in charge.

36

ADDITIONAL COPIES

OF THIS PUBLICATION MAY BE PROCURED FROM

THE SUPERINTENDENT OF DOCUMENTS

GOVERNMENT PRINTING OFFICE

WASHINGTON, D. C.

5 CENTS PER COPY 

